GOVI

I 19.3

$849 .-F$

E DO NOT DESTROY OR THROW AWAY THIS PUBLICATION. If you have no further use for it, write to the Geological Survey at Washington and ask for a frank to return it

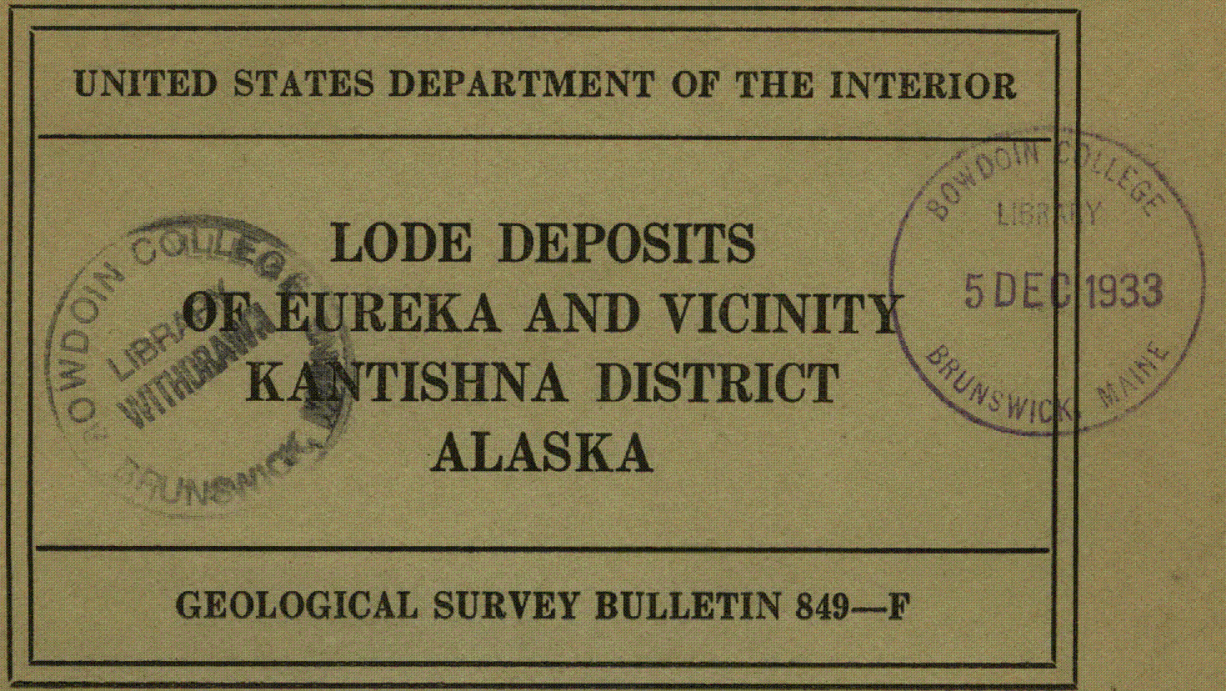




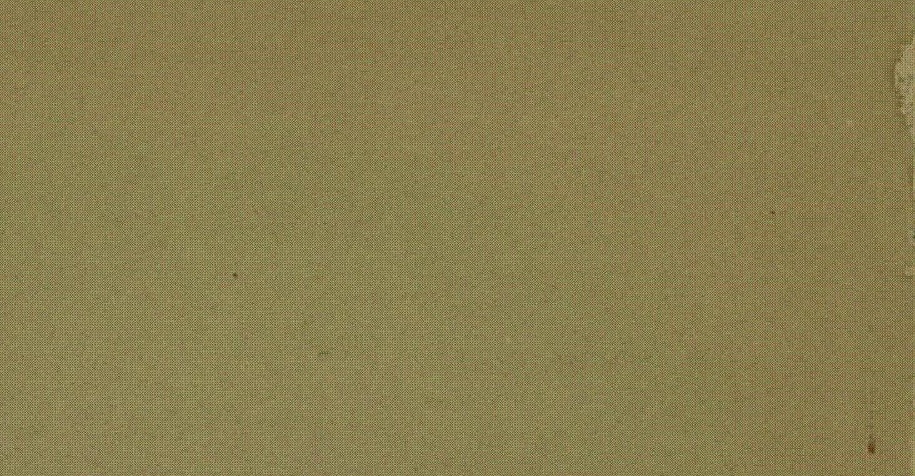

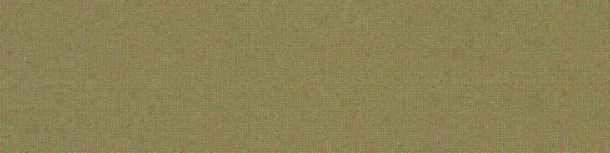
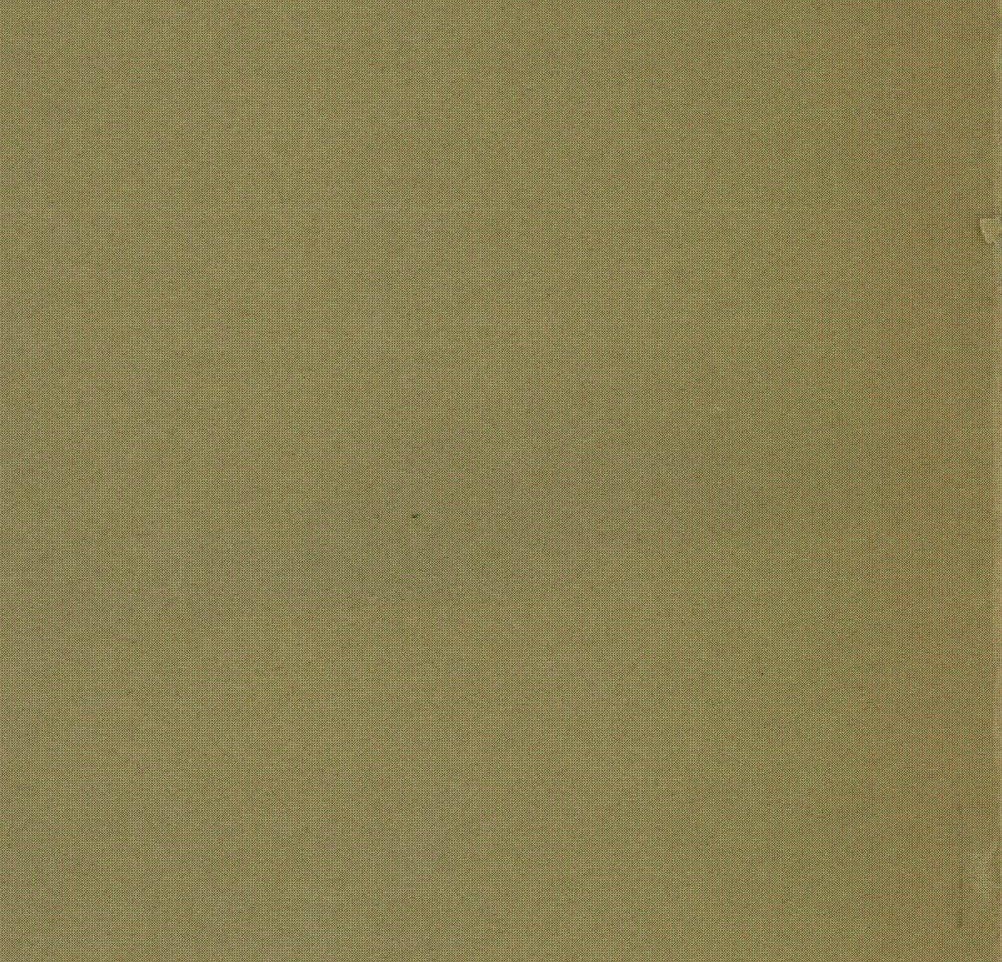
UNITED STATES DEPARTMENT OF THE INTERIOR

Harold L. Ickes, Secretary

GEOLOGICAL SURVEY

W. C. Mendenhall, Director

Bulletin 849 - F

\title{
LODE DEPOSITS OF EUREKA AND VICINITY KANTISHNA DISTRICT, ALASKA
}

\author{
BY \\ FRANCIS G. WELLS
}

Investigations in Alaska Rallroad belt, 1931

(Pages 335-379)

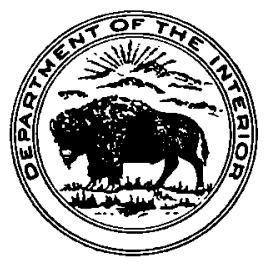

UNITED STATES

GOVERNMENT PRINTING OFFICE

WASHINGTON : 1933

For sale by the Superintendent of Documenta, Washington, D. C. - - - - Price 20 cents 



\section{CONTENTS}

Foreword, by Philip S. Smith

Abstract._.

Introduction

Location and means of access

Previous surveys

Field work and acknowledgments. 338

Geography _... 339

Drainage $\ldots \ldots$

Relief

Climate

Vegetation . . . . . 341

Population ................. 342

Geology

Principal features.

Birch Creek schist $\ldots \ldots \ldots 34$

Quartz-muscovite schist

Character and distribution $\ldots \ldots$

Structure............. 344

Limestone and chlorite schist.

Thickness and origin

Age and correlation

Igneous rocks_..... 347

Quartz porphyry

Diabase........ 348

Quaternary deposits......... 349

Glaciation and glacial deposits. . . . .

Postglacial deposits

Geologic history

Economic geology .......... 352

History of mining ..... 352

Character of ore deposits

Structural features . . . .

Mineralogy

Gangue minerals.

Metallic minerals

Gold quartz veins

Galena-sphalerite veins _......... 358

Stibnite veins

Oxidation and enrichment

Genesis of ore

Economic factors

Mines and prospects.... 360

Quigley Hill ........ 360

Red Top

Polly Wonder.

Little Annie. .............. 364 
Economic geology-Continued

Mines and prospects - Continued

Quigley Hill-Continued

Gold Dollar and Golden Eagle

Lucky Strike. .

Galena

Francis_...

Silver Pick and Little Maud. 368

Pennsylvania and Keystone

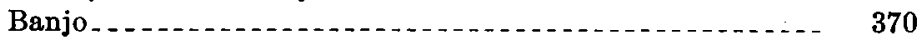

Damon and Pythias and Merry Widow 371

Glacier Creek

McGonogill ........ 372

Glen Creek...... 372

Glen

Glen Ridge No. 1

Arkansas and Pension

Humboldt.............. 374

Spruce Creek

Lena and Silver Wire

North Star

Eldorado Creek

Alpha

Neversweat. .

Antimony prospects. 376

Slate Creek

Home.... 377

Caribou... 377

Summary _. $\ldots \ldots \ldots \ldots$

Index

\section{ILLUSTRATIONS}

Page

Plate 28. Geologic map of Eureka and vicinity, Kantishna district _- In pocket 29. Sketch map of lode claims in the vicinity of Friday and Eureka

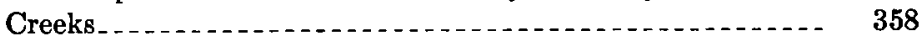

30. Assay map of Red Top tunnel .

31. Contour sketch map of Little Annie claim, showing tunnel_._- 366

32. Assay map of Little Annie tunnel . . . . . . . . . . . . . 366

Figdre 1. Index map showing areas investigated in Alaska Railroad belt, $1931 \ldots \ldots$ vII

45. Geologic sketch map and section of main tunnel of Red Top claim. 


\section{INVESTIGATIONS IN ALASKA RAILROAD BELT, 1931}

\section{FOREWORD}

\section{By Philip S. Smith}

To help the mining industry of Alaska and to assist in the development of the mineral resources of the Territory have been the prime motives of the Geological Survey's investigations in Alaska during the past 35 years, in which nearly one half of the Territory has been covered by its reconnaissance and exploratory surveys. It was natural, therefore, that the Alaska Railroad, when it undertook intensive consideration of the problem of finding tonnage that would increase its revenues, should look to the Geological Survey to supply technical information as to the known mineral deposits along its route and to indicate what might be done to stimulate a larger production of minerals and induce further mining developments and prospecting that would utilize its service. Realization of the need for this information had long been felt by the officials responsible for the operation of the Alaska Railroad, and the need had been partly supplied by the Geological Survey, but funds to carry through an extensive inquiry of this sort had not been available until 1930, when a special committee of the Senate, composed of Senators Howell, Kendrick, and Thomas, visited Alaska, studied some of the railroad's problems, and successfully urged Congress to grant it $\$ 250,000$ for investigations of this kind.

On the invitation of the Alaska Railroad the Geological Survey prepared various plans and estimates for the investigations that appeared to be most likely to contribute the desired information as to the mineral resources. Selection of the problems to be attacked proved difficult, because the choice necessarily was hedged about with many practical restrictions. For instance, each project recommended must give promise of disclosing valuable deposits-a requirement that was impossible to satisfy fully in advance, as it involved prophecy as to the unknown and undeveloped resources. Then, too, it was desirable that the search should be directed mainly toward disclosing deposits which if found would attract private enterprises to undertake their development in the near future. Finally, some of the deposits that might be worked profitably did not appear likely to afford much tonnage to be hauled by the railroad. Under these 
limitations it should be evident that the projects that could be recommended as worth undertaking with the funds available by no means exhausted the mineral investigations that otherwise would be well justified. In a large sense, all of Alaska may properly be regarded as indirectly contributory to the welfare of the railroad, but even in that part of Alaska contiguous to its tracks there are large stretches of country that are entirely unexplored and large areas that have had only the most cursory examination. Although areas of this sort might well repay investigation, they were excluded from the list of projects recommended because they were not known to contain mineral deposits of value, and it therefore seemed better to make the selection from other areas that had been proved to hold promise. Furthermore, several areas within the railroad zone were excluded because their value was believed to lie mostly in their prospective placers, which would not yield much outgoing tonnage; others because their lodes carried mainly base metals, for which development and the recovery of their metallic content in a readily salable condition were relatively expensive; and still others because their resources consisted mainly of granite, building stone, or some other product for which at present there is only a small local demand.

After careful consideration ten projects were selected, and the funds required for undertaking them were made available. The projects that were selected involved the examination of two areas principally valuable for their coal (Anthracite Ridge and Moose Creek), five areas likely to be principally valuable for gold (Fairbanks, Willow Creek, Girdwood, Moose Pass, and Valdez Creek), and three areas whose lodes consisted mainly of mixed sulphides (the Eureka area in the Kantishna district, Mount Eielson, formerly known as Copper Mountain, and the head of West Fork of Chulitna River). The general position of these different areas is indicated on the accompanying diagram (fig. 1). A general study of the nonmetalliferous resources of the entire region traversed by the railroad was included in the projects to be undertaken, but the results obtained were not such as to permit adequate determination of their extent at this time.

Examinations were made in the field in each of the selected areas, all the known prospects and mines being critically examined and sampled so far as time and other conditions permitted. The records thus obtained, together with all other information bearing on the problems, were then subjected to further study in the laboratory and office, in the course of which other Geological Survey specialists whose knowledge and experience could be of assistance were freely consulted. The outcome of all these lines of analysis has been the reports which make up this volume. Although each chapter is presented as embodying the latest and most authoritative information available regarding the districts and properties described up to the time field work in them 


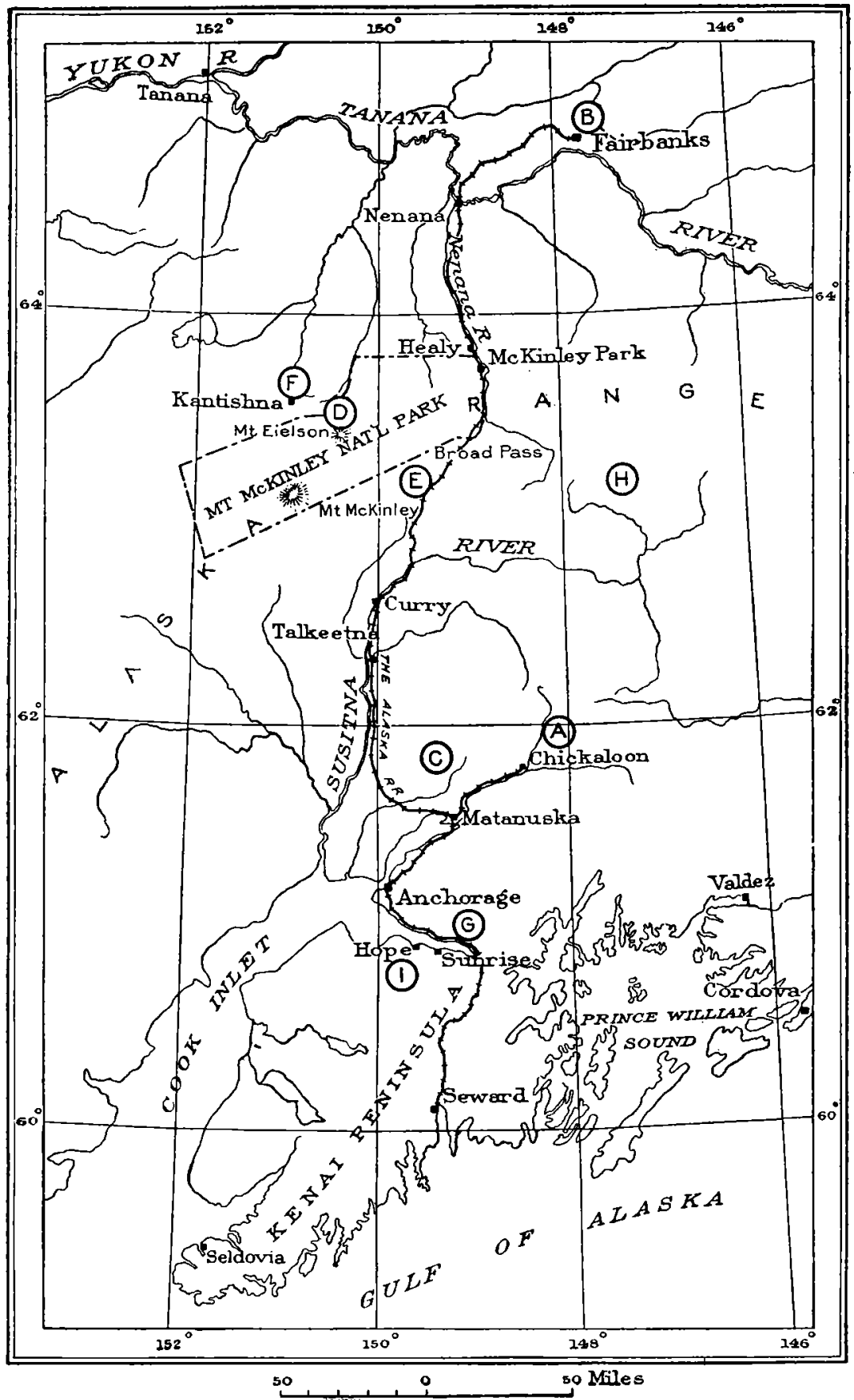

Figure 1.-Index map showing areas investigated in Alaska Railroad belt, 1931. A, Anthracite Ridge B, Fairbanks; C, Willow Creek; D, Mount Eielson; E, West Fork of Chulitna River; F, Eureks and vicinlty; G, Girdwood; H, Valdez Creek; I, Moose Pass and Hope. 
was finished, the authors make no claim that all the results they have presented are to be regarded as final nor as solving all the problems that have arisen. Actually none of the mines have been developed to such an extent as to furnish all of the evidence desired to solve the problems involved. At none of the properties is any considerable quantity of ore actually "blocked out" in the engineering sense of that term, so that instead of specific measurements as to the quantity and grade of ore the different camps will yield, the Survey geologists and engineers have necessarily had to make numerous assumptions and be content with estimates and generalizations as to the potential resources. Furthermore, the work was planned so as not to invade the proper field of the private mining engineer in the valuation of individual properties, but rather to occupy the open field of considering the districts as a whole.

In two of the districts, Anthracite Ridge and Moose Creek, whose value lay in their prospective coal resources, the examinations that could be made by ordinary geologic means were not adequate to arrive at a final judgment of the resources of the area but pointed to the desirability of further tests by drilling. As a consequence additional exploration of these districts by means of diamond drilling was authorized, and this work was undertaken in the season of 1932 . The results of these tests were not available at the time the manuscripts of the other reports were completed, and rather than delay their publication until the later reports could be finished and incorporated in the volume these reports have been omitted here and will be published later elsewhere.

This is not the place to summarize the detailed findings of the geologists as to the merits of the different districts, as those findings are explained in detail and summarized in the respective chapters. Suffice it to say here that on the whole the principal purpose of the investigations was carried through satisfactorily and that while the studies in some of the districts indicate that they hold little promise of extensive mineral development in the near future, others appear to encourage development under existing conditions, and still others seem to be worth development when some of the existing factors such as transportation or price of base metals are improved. That conditions which are now temporarily retarding the development of some of the deposits will become more favorable cannot be doubted. The entire region is becoming more accessible each year, and as a result costs are being lowered and experience is being gained as to the habit of the various types of deposits, so that the conclusions expressed in this volume as to the resources of the different districts should be reviewed from time to time in the light of the then current conditions. 


\title{
LODE DEPOSITS OF EUREKA AND VICINITY, KANTISHNA DISTRICT, ALASKA
}

\author{
By Francis G. Wells
}

\begin{abstract}
The Kantishna mining district is about 90 miles west of McKinley Park station on the Alaska Railroacl. The part of the district covered by this report comprises an area of about 72 square miles in the form of a strip 6 miles wide and 13 miles long.

The bedrock is mainly a metamorphic series of rocks which within the area has been differentiated into a quartz-muscovite schist and a calcareous facies that ranges from limestone to chlorite schist. A few small dikes of quartz porphyry and diabase intrude the schist. The general structure trends N. $70^{\circ}$ E., and from an axis that extends from Eldorado Creek northeastward to Spruce Peak the schistosity dips to the northwest and southeast. It is along this axis that the heaviest mineralization has occurred.

All the veins in the area strike N. $50^{\circ}-70^{\circ} \mathrm{E}$., and most of them dip at high angles toward the southeast, though a few dip toward the northwest. The veins are rudely tabular, swelling and pinching along both the strike and dip, and range in thickness from 23 feet to a fraction of an inch. Some of the larger veins have been opened by drifts or other excavations along the strike for 500 feet, but their surface croppings have been recognized for even greater distances.

The veins are of three types-gold quartz veins, silver-bearing galena veins, and stibnite veins. The gold quartz veins consist of white quartz containing small amounts of arsenopyrite and pyrite with scattered nests of galena or sphalerite. The gold is largely associated with the sulphide minerals except in the oxidized parts of the vein, where it is found as free gold. The galenasphalerite veins are composed preslominantly of sulphides carrying only small amounts of quartz and carbonate gangue. The ratio of galena to sphalerite is variable, and associated with these minerals are small amounts of tetrahedrite, stromeyerite, stephanite, and chalcopyrite, as well as pyrite and arsenopyrite. The stibnite veins are composed of stibnite with some quartz gangue, and many are massive stibnite. Enrichment appears to be almost totally lacking in all the veins, and they have been only superficially oxidized.

Some years ago about 1,300 tons of sulphide ore, most of which assayed better than $\$ 175$ a ton, with the major value in silver, then worth $\$ 1$ an ounce, was mined and shipped. The workings from which this ore was taken are now inaccessible. Of 104 samples taken from accessible quartz veins throughout the district the highest assay was 3.74 ounces of gold and 1.60 ounces of silver to the ton, and the average was 0.21 ounce of gold and 6.41 ounces of silver.
\end{abstract}


The area shows excellent indications of mineralization, and it is highly probable that other veins not yet mined contain ore of as high grade as that so far discovered. The type of mineralization, the character of the ore, and the absence of appreciable enrichment indicate that the ore extends to considerably greater depths than those so far reached in the area by mining developments.

\section{INTRODUCTION}

\section{LOCATION AND MEANS OF ACCESS}

The Kantishna region ${ }^{1}$ is broadly considered to be bordered on the south by the crest of the Alaska Range, on the north by the Tanana River, on the east by the Nenana River, and on the west by the lower Kantishna River. (See fig. 1.) This report on the lode deposits of Eureka and vicinity, however, treats only a small part of this region, an area 6 miles wide and 13 miles long, comprising the west end of the Kantishna Hills, between longitude $150^{\circ} 40^{\prime}$ and $151^{\circ} 10^{\prime} \mathrm{W}$. and latitude $63^{\circ} 30^{\prime}$ and $63^{\circ} 35^{\prime} \mathrm{N}$. During summer two routes of travel give access to the district-one from McKinley Park station on the Alaska Railroad by the McKinley Park road to Stony Creek and thence by trail to Kantishna, a distance of about 90 miles; the other by boat by the Kantishna and Bearpaw Rivers to Diamond, thence 25 miles by trail to Glacier and Kantishna. In the past the route by way of Diamond was most used, and practically all the freight has been moved over it. As the trail from Diamond to Kantishna is boggy and difficult of travel during summer the practice has been to bring supplies to Diamond by boat in summer and to haul them from Diamond to Kantishna by sled in winter. The cost of freighting by this route, as well as the time required to move materials over it, which is often more than a year, has been a serious obstacle to mining activities.

For winter travel a different route is chosen. This route leaves the Alaska Railroad at Kobe or Lignite, near the base of the foothills. From either of these points a trail leads westward along the south edge of the lowland to Knight's roadhouse, on the Toklat River, northwest of Mount Chitsia. Thence the Toklat River and its tributary Clearwater Fork are followed to Myrtle Creek. The trail follows Myrtle Creek up to a point near its head, crosses a low pass into the head of Spruce Creek, and descends that stream and Moose Creek to the vicinity of the mines on Moose, Eldorado, and Friday Creeks. The total distance along this route by sled from Fairbanks to Eureka Creek is about 165 miles.

The route from McKinley Park station is now being more widely used for travel, and with the completion of the road to Wonder Lake

1 Capps, S. R., The Kantishma region, Alaska: U.S. Geol. Survey Bull. 687, p. 7, 1919. 
it will be, at least during summer, the most rapid and easiest way for both men and materials to reach the Kantishna. In the summer of 1931 the road was complete to the Toklat River and was graded through Thorofare Pass, leaving a distance of about 20 miles to be both graded and graveled.

\section{PREVIOUS SURVEYS}

The first accurate survey covering part of the Kantishna region was made in 1902, when a United States Geological Survey party including A. H. Brooks, D. L. Reaburn, and L. M. Prindle left Cook Inlet by pack train, ascended to the head of the Skwentna River, and there crossed the Alaska Range into the Kuskokwim Basin. Proceeding northeastward they traversed the northwest slope of the Alaska Range to the Nenana River and followed that stream to its mouth. The results of this expedition form the first authentic information concerning the geography and geology of the Kantishna region and were published in a professional paper of the Geological Survey. $^{2}$ In 1906 Prindle $^{3}$ made a hurried visit to the Kantishna placer district, then recently discovered, and wrote a brief account of its geology and gold-placer deposits. Archdeacon Hudson Stuck ${ }^{*}$ passed through the Kantishna district in the spring of 1913 on his way to and from Mount McKinley and in his account of this expedition gives some information concerning the region. Likewise Charles Sheldon ${ }^{5}$ passed through the Kantishna district in the summer of 1906 and again in the summer of 1907 on his way to the north slope of the Alaska Range, and his book describing his explorations gives some additional geographic information.

The first survey of the area sufficiently thorough to determine the nature and distribution of the geologic formations as well as the character and extent of the economic resources was made in the summer of 1916, by S. R. Capps and C. E. Giffin, of the Geological Survey. Giffin prepared a topographic map of about 4,500 square miles on a field scale of 1 to 180,000 , while Capps ${ }^{B}$ studied the geology of the area, making a special investigation of the geologic conditions in the vicinity of the placer mines and examining all the placer mines and most of the prospects, including placer gold deposits and the gold, silver, and antimony lodes.

\footnotetext{
2 Brooks, A. H., The Mount McKinley region, Alaska, with descriptions of the igneous rocks and of the Bonniffeld and Kantishna districts, by L. M. Prindle: U.S. Geol. Survey Prof. Paper 70, 1911.

${ }^{3}$ Prindle, L. M., The Bonnlfeld and Kantishna regions, Alaska : U.S. Geol. Survey Bull. 314 , pp. 213-221, 1907.

4 Stuck, Hudson, The ascent of Denali, Charles Scribner's Sons, 1914.

S Sheldon, Charles, The wilderness of Denall, pp. 3-9, 85-91, 108-112, Charles Scribner's Sons, 1930.

Capps, S. R., The Kantishna region, Alaska : U.S. Geol. Survey Bull. 687, 1919.
} 
Stewart ${ }^{7}$ visited the Kantishna region in 1920 and gave a brief description of the camp.

A. H. Brooks ${ }^{8}$ and S. R. Capps, ${ }^{9}$ both of the Geological Surrey, made brief visits to the district in 1921 and 1922 , respectively.

J. A. Davis, of the Bureau of Mines, made a study of the lode deposits of the Kantishna district in the fall of 1922, and his description of the claims of the district was published in the annual report of the mine inspector to the Governor of Alaska for the year 1922.

F. H. Moffit, ${ }^{10}$ of the Geological Survey, spent 6 weeks in this region during the summer of 1930 for the purpose of gathering additional information about the mines and placers with the view of determining the possibilities of future production from this district.

\section{FIELD WORK AND ACKNOWLEDGMENTS}

The field work for this report was done during the summer of 1931. The party of 5 men, consisting of the writer as geologist and chief, S. C. Kain, topographer, a recorder, a cook, and a packer, with 7 horses, left McKinley Park station June 10 and returned to the station September 8, spending 77 days in actual field work exclusive of the time of travel to and from the railroad.

Flying levels were carried into the district from the nearest precise level bench mark, which was at McKinley Park station, by Mr. Kain. The primary control for the topographic map on a field scale of 1 to 48,000 (see pl. 28) was made according to the usual methods employed by the Alaskan branch of the Geological Survey, and the topography was mapped by the usual plane-table and traverse methods.

From the middle of July to the end of the field season the peaks and ridges were frequently covered with fog, thereby greatly retarding the progress of topographic mapping, and much of the time it was so rainy or foggy that satisfactory work could not be done. Consequently the field season came to an end with the boundary of the map not completely filled out.

The writer takes this opportunity to thank all those whose help contributed to the success of the project-the Alaska Railroad, especially Col. O. F. OhIson; the Alaska Road Commission, especially Mr. C. Edmonds, whose generous assistance expedited the journey from McKinley Park station to the field; Messrs. Lee Swisher and

\footnotetext{
'Stewart, B. D. (Territorial mine inspector), Annual report for 1920, pp. 12-14, Juneau, 1921.

${ }^{8}$ Brooks, A. H., The Alaskan mining industry in 1921: U.S. Geol. Survey Bull. 739, pp. 35-37, 1923 .

${ }^{\circ}$ Capps, S. R., Geology and mineral resources of the region traversed by the Alaska Railroad: U.S. Geol. Survey Bull. 755, pp. 141-144, 1924.

${ }^{10}$ Moffit, F. H., The Kantishna district, Alaska: U.S. Geol. Survey Bull. 836, pp. $301-338,1932$.
} 
N. Anderson, of the National Park Service; Mr. and Mrs. J. B. Quigley, for their hospitality and assistance at all times; Messrs. C. A. Trundy, O. M. Grant, John Busia, and Charles Greiss, for their hospitality; and all the miners in the district, who were always willing to assist.

\section{GEOGRAPHY}

\section{DRAINAGE}

The general features of the area are shown on the map (pl. 28). The western part of the Kantishna Hills lies within the drainage basin of the Bearpaw River, a tributary of the Kantishna River. The drainage forms a reticulate pattern consisting of creeks flowing in general northeast or southwest and of others flowing northwest or southeast. As the area considered forms part of the headwater portion of the Bearpaw drainage basin, most of the streams flowing through the area have their source within its confines and are consequently short, flow in narrow valleys, and have steep gradients, ranging from 150 to 600 feet to the mile. The only exception, Moose Creek, the largest stream in the area, the floor of whose valley is about a quarter of a mile wide, has an average grade of 50 feet to the mile. Moose Creek flows nearly westward across most of the southern part of the area, then turns and flows toward the north. Tributary to Moose Creek from the north are Spruce, Glen, Dry, and Rainy Creeks and tributaries too small to be named. Spruce Creek. about 3 miles long, flows toward the southeast with an average grade of 300 feet to the mile. Glen Creek is about 4 miles long and has a grade of 300 feet to the mile; 3 miles from its mouth it receives a branch from the east called East Fork, and above it the main stream: is called West Fork. The lower part of Glen Creek, like the lowe! part of Spruce Creek, flows through a narrow canyon. Rainy Creek is about 3 miles long. In its upper course the creek flow: southwestward, but about 2 miles above its mouth it turns abruptly and flows to the southeast. The longest tributary of Moose Creek. Eldorado Creek, is about 5 miles long. Entering Moose Creek from the southwest through a narrow steep-walled canyon about a quarter of a mile long, it flows in its upper course with a grade that diminishes from 150 to 50 feet to the mile through a constantly wideningr valley. Eureka Creek, which enters Moose Creek from the northeast at a point just opposite Eldorado Creek, is about 4 miles long and flows through a gorge in its lower course with a grade of 300 feet to the mile. Friday Creek is small but important because of the fact that it has yielded considerable gold. It enters Moose Creek from the northeast, is 2 miles long, and has a gradient that averages 600 feet to the mile. 
The second largest stream in the area is Glacier Creek, a tributary of the Bearpaw. Glacier Creek flows toward the northwest within the confines of the area, but it gradually turns and enters the Bearpaw River from the south. The valley of Glacier Creek is narrow and steep throughout its length and in its lower part is a canyon. Glacier Creek receives little drainage from the north, but tributary to it from the south are Twenty-two Gulch and Yellow Creek, short, swift streams occupying narrow, steep valleys. Caribou Creek, which lies just to the north of the area mapped, flows north and parallel to Glacier Creek on the east. It not only parallels Glacier Creek, but its valley is very similar. Like Glacier Creek, Caribou Creek receives little drainage from the north, but Crevice, Last Chance, and Snowshoe Creeks enter from the south. Those creeks, each about 3 miles long, occupy steep valleys and head against the ridges on the northern boundary of the area.

\section{RELIEF}

When viewed from the north the Kantishna Hills are seen to rise from the valley of the Kantishna River, a part of the Tanana lowlands, as a mass of large rounded hills with a relatively flat crest that slopes steeply toward the southwest. Although from a distance the region appears to be one of gentle slopes and low relief, this is not the case, for the hills rise from the lowland at an elevation of about 600 feet to 4,960 feet at the top of Kankone Peak, the highest point in the area. The area has been thoroughly dissected, and though the ridge tops are nearly flat or rounded, the valleys are narrow and sharply incised and have steep slopes.

What has been said for the Kantishna Hills in general is equally true of the specific part that is the subject of this report. The valley of Moose Creek ranges in elevation from 1,500 to 2,000 feet, and the ridge tops range from about 3,000 feet to a high point of 4,750 feet on Spruce Peak. The ridge tops have a general slope southwestward but in detail are marked by knobs and shallow saddles. With the exception of Moose Creek the valleys are all narrow and steep, but they tend to broaden out toward their heads. The eastern part of the area is the most highly dissected, consequently the ridge tops there are narrower, and their general northeasterly trend is not so pronounced; toward the west, however, where the surface is less dissected, it shows a smoother slope toward the lowlands.

\section{CLIMATE}

The Kantishna district lies within the climatic province of the Tanana and Yukon Valleys, and in general its climate is similar to that of the province as a whole. Owing to its position just north 
of the highest portion of the Alaska Range, however, its climate shows some marked differences.

At present there is no weather station within the district, though one was maintained at Wonder Lake from 1925 to 1929. The records taken at that time may be supplemented by the records of the McKinley Park weather station, which has been maintained since December 1922 and which, being situated on the north flank of the Alaska Range, is in a somewhat analogous position, though 63 miles to the east. Although the records for both stations are of short duration and incomplete, they serve as a basis for some general statements about the climate. ${ }^{10 a}$

The winters are long, and the summers have moderate temperatures. Unlike the Tanana Valley proper, this area is never hot during summer, and no month of the year is free from frost. Snow may be-expected any time after the first of September and rarely falls after the first of June, although 2 feet of snow fell on June 6, 1931. The rainfall is moderate, the greater part falling in the period from May to September. During summer the weather is squally, and even when the sky is not overcast showers may be expected.

\section{VEGETATION}

The Tanana lowland contains fair stands of spruce and cottonwood, especially along the courses of the larger streams and on the lower, well-drained slopes of the foothills, as well as some birch on the drier hillsides and tamarack and scrubby spruce in the marshes. Spruce trees furnish the only logs from which merchantable lumber is cut, and few of these exceed 24 inches in diameter at the base, so that they will probably furnish lumber only for local use. Timbered areas extend in narrow tongues from the lowland southward along the valleys of the main streams. Spruce is essentially limited to areas below 3,000 feet, though a few trees were seen as high as 3,700 feet. Even in the tracts below 3,000 feet in elevation there are large swampy areas in which trees are sparse or altogether lacking. Lumber and firewood must be hauled to practically all the placer claims on which mining is in progress. In most of the valleys, however, willow bushes large enough to furnish tent poles and fuel for the camper may be found at elevations several hundred feet above the upper limit of spruce, and it is upon such bushes that the prospector and explorer must depend.

Grass for horses can be found at almost any place where fuel can be had for the camp fire, and during summer it affords adequate forage for pack horses if they have sufficient opportunity to graze. The principal herbage on which the horses feed consists of redtop

10n Reed, J. C., The Mount Eielson district, Alaska: U.S. Geol. Survey Bull. 849-D, pp. 240-243, 1933. 
grass, bunch grass, and a vetch locally called pea vine. In autumn, however, early heavy frosts cause most of the grasses to lose their nutritive value, and horses must be fed on hay and grain if they are used for heavy work.

Blueberries grow profusely on the slopes above timber line and furnish a welcome article of food during August and September. A small wild cranberry is also abundant locally and is most palatable. Raspberries and currants occur within the timbered areas.

In the area here called Eureka and vicinity practically all the better timber has been cut. Though timber once extended up the valley of Moose Creek to an elevation of 2,700 feet and was fairly thick on the north side of the valley between Rainy and Spruce Creeks, this has been almost entirely removed, with the exception of small stands of poplar in parts of Moose Creek and a little spruce along the lower part of Rainy Creek, Number Four Gulch, a tributary of Glen Creek, and lower Spruce Creek.

On most of the creeks within the area success has been attained in the cultivation of garden vegetables, and one garden has been productive on the southeast side of a ridge at an elevation of 2,900 feet. Most of the miners give their gardens but scant attention after they are once planted, and yet they yield fair crops. Radishes, head lettuce, spinach, rutabaga, cabbage, cauliflower, potatoes, rhubarb, strawberries, and currants have been successfuliy grown. Garden flowers, including several varieties of poppies and pansies, and many native wild flowers bloom in profusion. The uniform success of vegetable and flower gardens through many successive years gives assurance that miners in the region can grow many of the vegetables they need.

\section{POPULATION}

The only permanent inhabitants of this region are the miners. Of the thousands of people who rushed into the region in the stampede of 1905 , when placer gold was discovered, practically all left when it became apparent that the deposits of gold-bearing gravel were neither so widespread nor so rich as had been imagined. The towns then built, Diamond, Glacier, and Eureka, were soon practically deserted. A few remained to work the creeks, however, and in 1916, according to Capps, ${ }^{11}$ there were some 40 or 50 men in the Kantishna region. In 1920-21, when Mr. Aitken was working the claims of J. B. Quigley, the population increased slightly, but when that work ceased it again dwindled, until in the summer of 1931 there were only 19 persons in the whole region, 14 of whom were in the area covered by this report. Roosevelt is now deserted; only one trader and a trapper live at Diamond, and two or three men who

11 Capps, S. R., The Kantishna region, Alaska: U.S. Geol. Survey Bull. 687, p. 18, 1919 
are on the creeks during the summer spend the winter there. One man lives at Eureka, and two other men winter there. Most of the inhabitants are placer miners who work the placers in summer and do some trapping in winter. Two of the number, J. B. Quigley and C. A. Trundy, are primarily interested in lode mining.

\section{GEOLOGY}

\section{PRINCIPAL FEATURES}

The bedrock of the Eureka and vicinity area is dominantly the Birch Creek schist. This formation here has two distinct faciesa quartz-muscovite schist and a calcareous schist ranging from limestone to chlorite schist. The only other rocks are the unconsolidated gravel deposits along the present streams and a few small dikes of igneous rocks that have intruded the schist.

\section{BIRCH CREER SCHIST}

The Birch Creek schist, of pre-Cambrian age, as exposed in this area has been divided on the basis of lithologic differences recognized in the field into a quartz-muscovite schist and a calcareous schist. Though the two types show considerable variation within themselves and in places seem to be gradational one into the other, yet in the main they are sufficiently distinct to warrant separate mapping. The distribution of these two types of rock is indicated by the map (pl. 28) so far as information is available.

\section{QUARTZ-MUSCOVITE SCHIST}

\section{CHARACTER AND DISTRIBUTION}

Characteristically the quartz-muscovite schist where well exposed and free from weathering effects is a gray schistose rock composed predominantly of quartz and breaking in large angular blocks. On many of the surfaces that are at an angle to the foliation no mica is discernible in hand specimens, but on others it can be readily recognized. On surfaces parallel to the foliation the silvery sheen of muscovite is a characteristic feature. The rock usually shows a general color banding in tones of gray, parallel to the foliation. Lenses and gash veins of milky-white massive quartz entirely free from discoloration by the oxidation of metallic sulphides are common and parallel the foliation, but they should be distinguished from the mineralized quartz veins that cut the formation and are described elsewhere (pp. 357-358).

This rock when viewed under the microscope in thin section is seen to consist of a mosaic of quartz with laths of muscovite showing a general alinement, usually lying between the quartz grains, though sometimes cutting them. In some specimens there are layers of $179399-33-\longrightarrow 2$ 
quartz mosaic a fraction of an inch thick relatively free from muscovite that are separated by layers of muscovite. Some sections show no feldspar; others show a little albite. In specimens containing albite, biotite is commonly present in small amounts. Another common mineral is garnet, which usually occurs in small crystals less than a sixteenth of an inch in diameter. Zircon crystals are occasionally found. On weathering the rock often becomes stained red or reddish brown, probably from the oxidation of the minute grains of pyrite scattered through the schist. Frost action tends to accentuate the foliation, and if muscovite is at all abundant the schist becomes very fissile.

Another variation of the schist is found in the canyons of Moose, Glacier, and Caribou Creelss. This rock is a highly micaceous schist, some specimens appearing to be composed of only mica and garnet. In such specimens the garnets are both abundant and large, measuring as much as three eighths of an inch in diameter. Hornblende metacrysts are found in some of the rock. In thin section the garnet schist shows a typical cataclastic texture and is composed of large grains of albite, muscovite, quartz, garnet, and clinozoisite. The muscovite is altered to chlorite along the cleavage lines, and the garnets show similar alteration along the fractures.

Scattered irregularly through the areas of outcrop of the quartzmuscovite schist and in places standing above the schist, owing to their greater resistance to erosion, are masses of greenstone. The greenstones range in color from gray with a green tinge to very dark green. Usually though not invariably granular in texture, they have the general appearance of igneous rocks, but on close inspection the rock is seen to be much altered and chloritized. Under the microscope such rocks are seen to contain chlorite, zoisite, quartz, albite, and in some specimens hornblende and calcite. The relative amounts of these minerals differ: some are predominantly albite and chlorite, others zoisite and chlorite, and still others hornblende and zoisite with only small amounts of the other minerals. These greenstones are undoubtedly derived from igneous rocks of intermediate composition. The fact that they are small in size and nowhere persist along the strike for more than a few hundred feet would indicate that they are intrusive into the original formation and are not flow rocks interstratified with it, and therefore they are not regarded as an integral part of the Birch Creek schist.

STRUCTURE

In this area metamorphism has almost obliterated the original structure of the formation, leaving as the only survival of its former presence some areas of color banding. Such color banding appears to be in general conformable to the planes of schistosity, and from 
this it has been assumed that in a general way the schistosity does not depart widely from the original bedding planes. The schistosity has a prevailing strike of northeast and dips to the northwest and southeast, away from an axis that roughly coincides with Eldorado Creek, Eureka Creek, and Spruce Peak, at angles that rarely exceed $60^{\circ}$. The nature of the schistosity therefore suggests a gentle anticline. Superimposed on this structure is a slight longitudinal folding; the folds are about 25 feet from crest to crest and have an amplitude of about 5 feet and give to some small outcrops an apparent dip that is at an angle to the dip of the major structure. The schist is cut by both joints and faults, which strike northwest.

The dikes and veins in the area are concentrated along this structure, and it is probable that the longitudinal fissures developed along the crest of the anticline during folding were an important factor in determining their emplacement.

The garnetiferous schist that is exposed in the canyons of Moose, Glacier, and Caribou Creeks is in many places highly contorted, showing drag folds, and this characteristic, combined with the nature of the metamorphism, suggests a zone of structural deformation.

\section{LIMESTONE AND CHLORITE SCHIST}

The metamorphosed calcareous sediments form a discontinuous band of outcrops which ranges in width from 1,000 to about 4,000 feet. This band strikes N. $75^{\circ} \mathrm{E}$. Its location is shown on plate 28 . The metamorphosed calcareous sediments in general are markedly different from the quartz-muscovite schists in which they occur. They are especially well displayed in the excellent exposures on lower Eldorado Creek, on the ridge south of Ruby Creek, and on the ridge between the head of Spruce Creek and the East Fork of Glen Creek. In their most distinctive form they are limestones, usually slate-gray in color, though they grade into black and, where weathered, into light gray. The rock is thinly laminated, showing bands ranging from less than one sixteenth of an inch to half an inch thick. Though banding is always visible on close examination, weathering brings it out very clearly, so that weathered surfaces look like thin-bedded granular deposits. The rock is predominantly calcite, effervescing freely in dilute hydrochloric acid, and some bands consist of coarsely crystalline calcite showing cleavage plainly. The microscope shows that the rock is completely recrystallized. Some specimens are practically all calcite; others have layers containing considerable quartz and albite and small well-formed crystals of zircon, and this type has more or less chlorite, which usually occurs as bands. The rock is highly jointed and breaks into small polygonal or rhombic slabs or blocks. Included in the limestone are beds of thinly laminated quartzite. 
The limestone grades upward into chlorite schist, a green, thinly foliated rock composed almost entirely of chlorite, some of which shows incipient alteration to biotite and a little quartz. The chlorite schists in turn grade into a thinly foliated rock consisting of layers of quartz mosaic separated by layers composed largely of zoisite with some muscovite. All these variants are characterized by the habit of breaking into rhombic or polygonal slabs or blocks, a distinctive feature that has often caused the rock to be called a slate.

Another variant, graphite schist, should also be noted, for though not confined in occurrence to the limestone chlorite schist it is most frequently found associated with that group of rocks. No large outcrop of this type of schist was seen, but many fragments of schist rich in graphite were found. It seems to be most abundant where faulting has taken place and may be a result of the metamorphism of the organic carbonaceous matter in the original sediment.

The structure of the limestone and chlorite schist so far as could be determined, is concordant with the structure of the quartzmuscovite schist.

\section{THICKNESS AND ORIGIN}

Inasmuch as neither the base nor the top of the Birch Creek schist is recognized within the area, its thickness could not be determined. 'To judge from the known area of outcrop the thickness of the formation must be very great, but in the absence of a detailed study of a complete section any figure for thickness would be only a rough approximation.

The preceding description of the Birch Creek schist indicates. clearly that it was derived from sedimentary material. This material was dominantly a rather pure sandstone, but included in it was a highly calcareous facies. The formation was intruded by igneous. rocks of intermediate or basic composition and then subjected to regional metamorphism. During metamorphism the character of the original rocks was completely changed: the sandstone became a quartz-muscovite schist, the limestone was recrystallized, the gradational material containing considerable quartz, calcite, and feldspar was turned into chlorite and zoisite schist, and the igneous material was altered to greenstone.

\section{AGE AND CORRELATION}

The Birch Creek schist was first described and named by Spurr, ${ }^{1 * 2}$ from Birch Creek, a tributary of the Yukon River. Prindle ${ }^{13}$

${ }^{13}$ Spurr. J. E., Geology of the Yukon gold distriet, Alaska : U.S. Geol. Survey Fighteenth Anv. Rept., pt. 3, pp. 140-145, 1898.

${ }^{13}$ Prindle, I. M., Gold placers of the Fairbanks district, Alaska: U.S. Geol. Survey Bull. 225. p. 67, 1904 : The gold plucers of the Fortymile, Birch Creek, and Fairbanks regions, Alaska: U.S. Geol. Survey Bull. 251, pp. 27-29, 1905. 
extended the name on the basis of continuous outcrop to include the metamorphic rocks of the Fairbanks region, and Brooks and Prindle ${ }^{14}$ applied the name to the metamorphic rocks in the Kantishna region on the basis of similar lithologic characteristics. Capps ${ }^{15}$ continued the usage of Brooks and Prindle, and the writer has no evidence that is opposed to this correlation.

Mertie ${ }^{16}$ has definitely shown that in the east-central part of Alaska the Birch Creek schist is of pre-Cambrian age. In the Kantishna area there are no reference horizons that permit dating this group of rocks so definitely, but, on the other hand, there is no evidence which would preclude such an assignment. Therefore a pre-Cambrian age for these old schists in this area has been adopted.

\section{IGNEOUS ROCKS}

In addition to the greenstones already mentioned, outcrops of igneous rocks are limited to seven small areas, none of which exceed 3,000 feet in largest dimensions, scattered along the central part of the district. Though the igneous masses were poorly exposed and the actual contacts with the enclosing schist were not seen, yet the fact that they occur as relatively long, narrow bodies was evident, and they are consequently considered dikes. These later igneous rocks have been divided into an acidic type represented by quartz porphyry and a basic type corresponding to diabase.

\section{QUARTZ PORPHYRY}

The quartz porphyry is best seen on Friday Creek, about half a mile upstream from the mouth. Here in the bottom of the creek it is exposed for a distance of 1,400 feet, and large boulders of it are found downstream from the outcrop. On exposed surfaces the rock is pink, but on the fresh fracture it is a light-gray rock in which the numerous phenocrysts of quartz and feldspar, usually about 2 millimeters in diameter, stand out conspicuously. The groundmass is fine-grained. Under the microscope the phenocrysts of quartz are seen to be rounded and bayed by corrosion and surrounded by aureoles of graphically intergrown quartz and feldspar. Such aureoles also surround the phenocrysts of orthoclase, and patches of similar material are found in the groundmass. The groundmass consists of microcrystalline quartz and feldspar. The orthoclase phenocrysts, as well as the groundmass, are partly altered to seri-

\footnotetext{
${ }^{14}$ Brooks, A. H., The Mount McKinley region, Alaska, with descriptions of the igneots rocks and of the Bonnifeld and Kantishna districts, by L. M. Prindle : U.S. Geol. Survey Prof. Paper 70, pp. 56-60, 1911.

${ }^{15}$ Capps, S. R., The Kantishna region, Alaska : U.S. Geol. Survey Bull. 687, pp. 26-29, 1919.

1i Mertie, J. 16., Jr., Grology of the Eagle-Circle district, Alaska : U.S. Geol. Survey Bull. S16. np. 17-21, 1930.
} 
cite and partly to calcite, and in the groundmass laths of muscovite have been developed.

A somewhat larger mass of this type of rock crops out on Eldorado Creek. (See pl. 28.) Here, however, the rock is highly altered, the phenocrysts of quartz and feldspar as well as the groundmass: being completely sericitized or in places changed to calcite. Scattered through the rock are many fine grains of pyrite, and many of the weathered specimens are stained brown by the limonite formed from the pyrite. Rocks of similar character are exposed on the ridge lying north of the upper parts of Eureka and Yellow Creeks.

\section{DIABASE}

Dikes of basic igneous rocks are found on the ridge between Yellow Creek and Twenty-two Gulch and in the saddle between Iron Gulch and Twenty-two Gulch. At the first-named locality a dike that strikes $\mathrm{N} .70^{\circ} \mathrm{W}$. can be traced for a distance of 1,200 feet. It is probably not more than 100 feet wide. In hand specimen the rock is dark gray and granular; under the microscope it shows a diabasic texture formed of interlocking laths of labradorite with interstitial augite and a little quartz. The rock has suffered much alteration, the feldspar being largely changed to saussurite and then tocalcite, while the ferromagnesian mineral has altered to biotite and chlorite or even to calcite. From its texture and mineral composition the rock is identified as a diabase.

The dike between Iron Gulch and Twenty-two Gulch strikes N. $60^{\circ} \mathrm{W}$., is 80 feet long and 30 feet wide, and rises as a little ridge above the schist. Though related to the diabase, it has a slightly different appearance, being black and very fine grained. Under the microscope the rock is seen to consist of small interlocking laths of labradorite, between which occurs biotite. It is identified as a kersantite.

No other intrusive basic igneous rocks are found in the area, but as already mentioned there are many masses of greenstones which have not been differentiated in mapping from the Birch Creek schist, although they are not considered to be part of that formation. Some of these greenstones may resemble at first sight the intrusive diabase, but if examined carefully they usually show the presence of chlorite and zoisite, and under the microscope their metamorphic nature can easily be detected. (See p. 344.)

No definite evidence is available as to the precise age of these intrusive rocks. That they are younger than the Birch Creek schist is evident. In the Alaska Range, 20 miles to the south, both intrusive and extrusive igneous rocks are found, but they are dissimilar in general chemical and mineral composition. 


\section{QUATERNARY DEPOSITS}

\section{gLACIATION AND GLACIAL DGPOSITS}

No glaciers are found within the Kantishna Hills, and none of the peaks are high enough to maintain perpetual snows. Furthermore, during the last glacial stage only the heads of Glen, Glacier, and Caribou Creeks were high enough to support small ice tongues, which never attained sufficient length to reach beyond the confines of their narrow valleys. Nor were the hills overridden by the large glaciers that descended the Alaska Range to the south and at that time extended much farther to the north than at present. It is known, however, that at some time Muldrow Glacier, which is much the largest glacier on the north slope of the Alaska Range and now ends south of the Eureka and vicinity area, pushed northward beyond its present terminus, overflowed the divide between McKinley Fork and upper Moose Creek, and sent several ice lobes down Moose Creek as far as Friday Creek and into Stony and Boundary Creeks. Wonder Lake lies in the glacial basin excavated by the ice that moved northward into Moose Creek; the pond north of Moose Creek opposite Wonder Lake, also the small ponds north of Moose Creek between Rainy and Glen Creeks, as well as the peculiar courses followed by Spruce and Glen Creeks, testify to its presence at these places. Though the ancient glacier left no deposits having strongly marked topographic expression within the area mapped (pl. 28), evidence of its effect is furnished by the large boulders of coarse pink granite brought down from the Alaska Range, which are found on the ridge east of Wonder Lake, throughout the length of Eldorado Creek, and in the lower courses of Glen, Rainy, and Friday Creeks. Such glacial erratics were found in Friday and Eureka Creeks as high as the 2,000-foot contour and in Glen Creek and Eldorado Creek up to the 2,400-foot contour. On the ridge east of Wonder Lake and also along the southwest boundaries of the area large erratics occur at an elevation of 2,900 feet, but elsewhere in the area they are never found above 2,400 feet. It seems probable, therefore, that the erratics found at the higher level were not deposited by the advance of Muldrow Glacier that pushed a lobe through Wonder Lake and down Moose Creek but by an earlier advance, when the glacier overrode the high land south of Moose Creek and probably banked up on the hills just to the north. Erosion, however, has removed all traces of the presence of the ice north of Moose Creek.

Little can be said as to the precise time of these two ice advances, and on the basis of the present evidence it is impossible to correlate them with the advances and retreats of the continental ice sheets that invaded the northern United States in Pleistocene time. The 
earlier advance, however, which was of sufficient magnitude to ride over the high ridges, must have occurred during one of the Pleistocene stages of glaciation, and it is probable that the later advance likewise took place in the Pleistocene, though some more recent local climatic changes might possibly have been sufficient to cause Muldrow Glacier to advance to Moose Creek, only 10 to 12 miles north of its present terminus.

\section{Postghaciat deposits}

Bordering both banks of Moose Creek and standing at various levels above the flood stages of the present stream are terraced gravel deposits. The gravel is related to the present topography, having been deposited by Moose Creek when a temporarily higher baselevel lower in its course caused the heavily loaded stream to build up a deposit of gravel on its wide valley floor. As this baselevel was lowered Moose Creek began to cut away the gravel deposits, but in the process of deepening its channel it encountered hard-rock obstructions. Wherever this happened the checked stream began to meander and widen its flood plain and has left a record of this process in the successively lower terraces that are found along its course. Three well-preserved terrace levels occur along the creek, and in its upper course there are still others. The terraces reach their greatest development east of Willow Creek, where they are in places more than half a mile wide, and the maximum exposed thickness of the deposits is about 75 feet. (See pl. 28.) In material, degree of assortment, and structure they have all the characteristics of stream deposits. They show no oxidation from weathering.

The gravel deposits of the present streams are found essentially at the level of the streams and are subject to overflow in periods of high water. They consequently occur as long, narrow bands following the stream courses. The width of the belt of gravel along any stream depends on the size of the stream and the shape of its valley. Within the mapped area these deposits, except those in the valley of Moose Creek, are nowhere more than 200 feet wide and are usually not more than 5 feet deep, though in parts of some of the streams they reach a depth of 10 to 15 feet, and in a ferw places even greater thicknesses have been encountered. The material is derived from the small basins drained by the creeks and is in consequence poorly sorted gravel, coarse and subrounded. Here and there thin layers of "muck" are interstratified with the gravel. In these gravel deposits are found many of the placer gold deposits of the region, and the gold like the gravel, has been derived from the bedrock that forms the nearby slopes, has traveled but a short distance from the veins in which it originated, is consequently coarse, rough, and angular, and 
frequently has some of the quartz from the vein attached to it. 'The gravel in the valley of Moose Creek is derived in large part from the reworked terrace gravel that occurs along the course of its valley as well as from material derived from the Birch Creek schist, much of which is brought down by its tributaries. The reworked terrace gravel has been shown to be partly of glaciofluvial origin; consequently it consists not only of the subrounded boulders derived from the Birch Creek schist but also of well-rounded material, the original source of which was the Alaska Range. This gravel is nowhere thick, but from the head of the rock canyon 2 miles below the mouth of Friday Creek to a point north of Wonder Lake it is reported to lie on a false bedrock of blue clay, sand, and semiconsolidated gravel. At one place a pit sunk in this underlying gravel to a depth of about 40 feet failed to reach true bedrock. All traces of this pit were obliterated when the site was visited in 1931, but Mr. Capps, ${ }^{17}$ who in 1917 examined the excavated material. described it as postglacial stream gravel.

\section{GEOLOGIC HISTORY}

The formations that crop out in the area mapped are limited to the Birch Creek schist, of pre-Cambrian age; recent unconsolidated deposits along Moose Creek; a few igneous intrusives; small exposures of Tertiary deposits just north of the area ; and erratic boulders scattered in the creeks and along the ridges in the southern part of the area. Only a very fragmentary part of the history of the area can be deciphered within the area, and even when the evidence found in immediately adjacent regions is utilized, the history remains far from complete.

In pre-Cambrian time the Kantishna district, in common with much of the Tanana Valley, was a basin of deposition, receiving sedimentary material from a land mass, the site of which is not yet known. The sedimentary material was largely clastic and arenaceous and to judge from its nature was probably laid down in shallow water. The great thickness of material deposited would indicate that sedimentation was continued for a long period. This period was followed by the intrusion of igneous rocks, the folding and metamorphism of the sediments, and the elevation of the region above sea level.

Then followed a period of erosion which in this area may have continued without interruption until Tertiary time. However, the region to the east and west along the Alaska Range, as well as the Cosna-Nowitna region, which lies to the northwest, is known to have

\footnotetext{
${ }^{17}$ Personal communication.
} 
been invaded by the sea many times since the pre-Cambrian, ${ }^{18}$ and it seems not unlikely that the Kantishna district was likewise subjected to some of these marine invasions, especially those of Paleozoic time. If such marine invasions took place, all record of them has been obliterated in the district under consideration.

The history during all the Mesozoic and the early part of the Tertiary is obscure. Probably at some time during this interval granite and diabase dikes were intruded. In Tertiary time the northward-flowing streams of the Alaska Range were steepened and rejuvenated by the uplift of the mountain mass and were enabled to carry more and coarser material than formerly. On reaching the edges of the lowland to the north they deposited this gravel as a great alluvial sheet. As the uplift of the Alaska Range continued more and more of the lowlands were involved in this process of deposition, and the rivers cut their valleys more deeply into the rocks of the mountains.

In Pleistocene time a change of climate occurred, perhaps involving an increase in precipitation and a colder mean annual temperature. Glaciers were formed, and those on the north flank of the Alaska Range pushed their fronts far down the valleys and even out into the lowland beyond the mountains, advancing to the Kantishna Hills and pushing a lobe down Moose Creek. Small glaciers formed in the heads of the valleys of the Kantishna Hills. Later an amelioration of the climate caused the glaciers to retreat, but apparently glacial conditions recurred and once more caused the ice to advance until it reached the southern edge of the Kantishna Hills. Once again a period of waning of the glaciers ensued, and with their retreat stream erosion was resumed in the region. The streams began to deepen their valleys until some local baselevel temporarily checked their downcutting, causing them to broaden their valleys slightly and form the terraces now found along many of the major streams. With the cutting through of these temporary baselevels the streams again began to entrench themselves, and they have continued this process until the present day.

\section{ECONOMIC GEOLOGY}

\section{HISTORY OF MINING}

In 1903 Hon. George Wickersham, at that time judge of the third division of Alaska, conducted an expedition from Fairbanks to the head of navigation on the Kantishna River and then went overland to Mount McKinley. While traversing the Kantishna Hills he

\footnotetext{
${ }^{18}$ Capps, S. R., The Kantishna region, Alaska : U.S. Geol. Survey Bull. 687, pp. 29-57, 1919 ; The Toklat-Tonzona River region, Alaska: U.S. Geol. Survey Bull. 792, pp. 87-100, 1927. Eakin, H. M., The Cosna-Nowitna region, Alaska: U.S. Geol. Survey Bull. 667, pp. 23-42, 1917.
} 
found gold in the gravel of some of the stream beds, and his report of the occurrence of gold there induced J. B. Quigley to go into the region. In June $1905 \mathrm{Mr}$. Quigley and his partner, Jack Horn, staked claims on Glacier Creek, and in July, on going over the hills to Eureka Creek, they found that Joe Dalton and his partner, Stiles, who had come into the area from the east, knowing nothing of Quigley's discovery, had already staked Eureka Creek. News of finds of coarse gold in shallow gravel in the Kantishna started a stampede into the area, but as soon as it was learned that the creeks were short and not very rich the prospectors who had rushed in left, so that by the fall of 1906 there were only about 50 men remaining on the creeks. These men continued to work the placers, and there has been a steady though small production since. The total production to 1931 is estimated as approximately $\$ 500,000$.

The existence of lode deposits must have been soon realized by the placer miners, for in some places on the creeks pebbles of galena and stibnite were so abundant that they caused considerable trouble in the sluice boxes by filling up the riffles. Likewise large boulders of stibnite weighing many hundreds of pounds were encountered in sluicing, and in some places the lodes cropped out so conspicuously that the prospectors could not fail to see them. Such a lode of stibnite cropped out on Last Chance Creek at its confluence with Caribou Creek, and the high price of antimony during the Russo-Japanese War induced Mr. Quigley and his partner to mine and ship some of this stibnite, but before the ore had reached the market the price of antimony fell, and the ore was abandoned. Mr. Quigley's interest in lode mining being aroused, he has continued to prospect ever since, and the development of the lodes of the Kantishna district is mostly a result of his efforts.

Some prospecting was done on Glacier Peak and at the forks of Glen Creek from 1906 to 1909 by a company formed for the purpose by Tom Lloyd. This same group did some work in 1912 on a deposit on Slate Creek. Other prospectors, including William Taylor, Charles McGonogill, and Charles A. Trundy, held claims in the district. In 1920 T. P. Aitken leased the Quigley claims, from which he mined and shipped about 1,200 tons of silver-lead ore. This stimulated prospecting, but interest soon waned when it was realized that the search would take a long time and cost much money and effort. Mr. Quigley, however, continued to prospect and in 1923 made a further shipment of ore. Except for the prospecting of Messrs. Quigley and Trundy there has been no lode-mining activity in the Kantishna region since then, and most of the prospects other than the patented claims have lapsed. 
The total shipment of ore from the lodes of the Eureka and vicinity area has been slightly in excess of 1,300 tons of lead-silver ore, practically all of which came from the claims of J. B. Quigley. The ore that has been shipped from the Quigley property ranged in value from $\$ 128$ to $\$ 400$ a ton (silver at $\$ 1$ an ounce), and three quarters of it exceeded $\$ 179$ a ton. About 10 tons of lead-silver ore is reported to have been shipped in 1921 from the Alpha claim, now owned by Lawrence Ferrar. This ore is said to have assayed more than $\$ 200$ a ton (silver at $\$ 1$ an ounce). The major part of the value was in silver, although some of the ore contained as much as 2.5 ounces of gold to the ton. No ore has been mined in the area for its gold content alone, however. A few tons of antimony ore was mined in 1905 and again during the World War, but none of the ore ever reached outside markets, though some of it was freighted to Roosevelt.

\section{CHARACTER OF ORE DEPOSITS}

The study of the veins of the area was hampered by the meagerness of accessible underground workings and the mantle of soil. Though many of the veins had formerly been exposed by both underground workings and a large number of open cuts, most of the openings are now caved and the open cuts are so filled in that the only existing evidence of the former presence of many of them is small depressions in the soil. Soil creep and sliding are so prevalent that even such depressions cannot be assumed to be in place, nor is it safe to depend solely on the distribution of material lying on the surface. Parts of eight tunnels with an aggregate length of 1,800 feet were accessible in the summer of 1931 . The longest drift along a vein was about 500 feet, and the greatest depth attained below the surface was about 90 feet. It was practicable to clean out a few of the old open cuts, but the work necessary to open up caved workings was too great to be undertaken for the purposes of the present investigation. The statements that follow, therefore, are based in large part on information obtained by earlier workers in the region, especially from reports by Capps, ${ }^{19}$ who visited the area in the summer of 1915 , by Davis,${ }^{20}$ who visited the area in the fall of 1922, and by Moffit, ${ }^{21}$ who visited the area in 1930, supplemented by observations made by the writer in 1931.

\section{STRUCTURAL FEATURES}

The strikes of all the veins in the district range from N. $30^{\circ} \mathrm{E}$. to due east, but most of the veins strike $\mathrm{N} .50^{\circ}-70^{\circ} \mathrm{E}$. As a rule

\footnotetext{
${ }^{10}$ Capps, S. R., op. cit. (Bull. 687), pp. 95-109, 1919.

${ }^{20}$ Davis, J. A., in Annual report of mive inspecter to the Goveruor of Alaska for 19:2., pp. 113-134.

${ }^{21}$ Moffit, F. II., The Kantishna district, Alaska : U.S. Geol. Survey Bull. 836, p1), 301338, 1932.
} 
the veins dip at angles from $60^{\circ}$ to nearly vertical toward the southeast, but a few veins dip at steep angles to the northwest. Each of the northwestward-dipping veins, however, intersects a southeastward-dipping vein. The strike of the veins in general is the same as that of the foliation of the country rock, but owing to differences in the dip of the veins and the dip of the foliation the veins cut the schist. This serves in a measure to distinguish the veins from the lenses of milky-white massive quartz, entirely free from discoloration caused by the oxidation of metallic oxides, that form part of the schist and that are parallel to its structure. The concentration of the veins along the anticline in the Birch Creek schist (p. 345) and their strike parallel to the axis of the fold strongly suggest that the veins were formed in longitudinal fractures developed in the schist by the folding.

The veins show considerable variation in width, from a maximum of 23 feet to a few inches. In general they are rudely tabular, swelling and pinching along both the strike and dip, or they are lenticular, pinching out at the ends but being succeeded along the strike by other lenses. In some places two or more parallel veins are separated by narrow layers of schist, and many of the veins include horses of schist. The contact of the rein and the hanging wall is usually sharp, in places being marked by a selvage of clay gouge a fraction of an inch thick, and the ore may show slickensiding. The footwall, on the contrary, is commonly cut by veinlets and stringers of mineral, and the contact is usually indefinite. Several of the veins are displaced by northwestward-striking normal faults, but the movement was not great, and the displacement is nowhere large. It is probable that the veins are fairly persistent along the strike. The vein on the Little Annie claim has been followed for 500 feet along the strike. The vein is strong in both ends of the drift and gives evidence of continuing both to the east and west. Little evidence is available on which to base a judgment as to the continuation of the veins in depth. To date the maximum vertical distance below the surface to which any vein has been opened up is 90 feet. From the nature of the mineralization, however, it seems reasonable to assume that the veins extend down the dip for several hundred feet.

\section{MINERALOGY}

\section{GANGUE MINERAIS}

Quartz, calcite, siderite, epidote, scheelite, and rhodonite are the gangue minerals reported from the district. Of these the writer has seen quartz, calcite, siderite, and epidote in place. Scheelite is reported from the Red Top vein by Paul Hopkins, and other occurrences have been reported. Rhodonite, however, though com- 
mon as large boulders in Glen Creek, has never been found in place. Quartz is the dominant gangue mineral. 'The carbonates are later than quartz and in places occur without accompanying metallic minerals. Epidote occurs as a small well-crystallized accessory mineral in the quartz, and the skarnlike rock that makes up part of Iron Hill and that contains arsenopyrite scattered through it has. a high epidote content.

\section{METALLIC MINERALS}

Gold, arsenopyrite, pyrite, sphalerite, chalcopyrite, galena, tetrahedrite, freibergite silver-bearing tetrahedrite, stromeyerite (a sulphide of copper and silver), bournonite (a sulphide of lead, copper, and antimony). stephanite (a sulphide of silver and antimony), stilnite, pyrargyrite (ruby silver), and oxidized products of these, scorodite (a hydrous ferric arsenate), azurite, cerusite, melanterite, and stibiconite and kermesite (antimony ochers) are the metallic minerals reported to have been found in the district. Of these minerals the writer has seen all but stromeyerite, bournonite. stephanite, pyrargyrite, and scorodite, and Paul Hopkins, who reported the presence of stephanite, stromeyerite, and bournonite, said that these minerals were not found in sufficiently large crystals for identification, so possibly mixtures of the simple sulphides were taken for these complex minerals. The relative abundance of these minerals is very different in different veins, but pyrite, arsenopyrite, sphalerite, galena, and stibnite are the most common.

The vein deposits in the district can be divided into three types on the basis of the predominant mineral present-(1) quartz-arsenopyrite-pyrite gold veins which contain scattered small bunches of galena and sphalerite; (2) galena-sphalerite-tetrahedrite-pyritechalcopyrite veins with but little gangue, which usually is carbonate, though some quartz is always present; and (3) stibnite-quartz veins, as a rule practically free from other minerals. The nests of galena and sphalerite found in the Little Annie quartz vein show under the microscope not only the arsenopyrite and pyrite typical of the quartz. veins but also the complete mineralogy of the galena-sphalerite veins, thus clearly indicating the relationship between these two. With the specimens available no relationship can be shown between the stibnite veins and the others, though the presence of antimony in such minerals as tetrahedrite and jamesonite would indicate that the stibnite belongs to this stage. Furthermore, in the Fairbanks district, ${ }^{22}$ where similar veins occur, this relationship has been definitely established.

2 Hill, J. M., The lode deposits of the Fairbanks district, Alaska: U.S. Geol. Survey Rull. 849-B, 1933 . 
The minerals in order of their deposition from oldest to youngest are arsenopyrite, pyrite, sphalerite, galena, chalcopyrite (overlap), tetrahedrite, jamesonite, and marcasite. Quartz came prior to the sulphide minerals, but calcite did not come until after arsenopyrite and pyrite.

\section{GOLD QUARTZ VEINS}

Several veins composed predominantly of quartz with gold as the valuable metallic constituent are found in the area. Of these, the Little Annie vein has been most extensively opened up by both trenching and tunneling and therefore offers the best opportunity for study, and the statements that follow are based largely on observations made at this vein, though applicable to the others.

The vein is composed of white quartz stained brown by iron oxides. Much of the quartz is shattered and breaks readily into small angular pieces, but even if it does not break readily the lines of fracture can be seen traversing the mass in all directions. In places the vein shows brecciation, angular pieces of white quartz cemented by other quartz and occasionally small patches of partly silicified schist being found. Rarely the quartz shows good crystal outlines. The metallic minerals arsenopyrite and pyrite occur as small well-formed grains which are seen only when the rock is examined closely. Bunches of galena and sphalerite from a fraction of an inch to an inch or more in diameter are found at places in the veins. With the help of the hand lens free gold can be seen in some of the quartz. The gold usually occurs either with or near the sulphides, much of it in ironstained cavities. In the Pennsylvania lode crystallized gold was found, and some of the largest dendritic pieces pounded out of the quartz by Mr. Quigley weighed as much as a tenth of an ounce each.

Under the microscope the quartz is seen to be a breccia composed of angular fragments of clear quartz surrounded by a fine-grained dirty quartz mosaic. Though all the quartz in any one fragment has the same crystal orientation, it has very irregular extinction, owing to crushing. Some veinlets of quartz cut these fragments. The space between the fragments of shattered quartz is filled with finegrained dirty quartz mosaic in which there are a few small crystals of clinozoisite. The crystals of arsenopyrite and pyrite usually occur in this interstitial mosaic, though here and there they lie in the large fragments along fracture lines. It is evident that after the deposition of some of the quartz movement took place along the vein whereby the quartz was fractured, some of it being finely comminuted, and then sulphides and additional quartz were introduced. A study of the distribution of sulphides in polished sections shows that movement continued in the vein until the end of sulphide 
mineralization. This fracturing followed the deposition of arsenopyrite; then pyrite, sphalerite, galena, and chalcopyrite were formed; further fracturing was followed by the deposition of jamesonite, which in turn was fractured; and the period of mineralization ended with the introduction of quartz and carbonates.

\section{GALENA-SPHALERITE VEINS}

With the exception of the Red Top vein and a few feet of the Alpha vein none of the galena-sphalerite veins were accessible when the writer visited the region, so the description of their larger features is derived mainly from previous reports, and most of the specimens studied in polished section were collected from the dumps. The veins consist predominantly of sulphides, and many a whole vein is a solid mass of sulphides. The most abundant of these are galena, sphalerite, and pyrite. Some of the veins are almost solid galena, part of which is very finely crystalline and part coarsely crystalline. If the vein matter is composed largely of sphalerite, pyrite and galena are present in noticeable amounts. Though chalcopyrite occurs as a conspicuous mineral at the Neversweat prospect, on Eldorado Creek, it usually occurs only in small amounts, and in many places its presence can be detected only by means of a lens. The same is true of the occurrences of tetrahedrite and the other silver-rich minerals jamesonite and pyrargyrite, which are rarely visible in hand specimens. The usual gangue minerals are calcite and sillerite, though quartz is everywhere present and may predominate.

\section{STIBNITE VEINS}

The stibnite veins consist of quartz and stibnite, and no other minerals except the oxidation products stibiconite and kermesite have been found associated with them. Many of the veins consist of solid stibnite containing no gangue mineral. The stibnite in places is coarsely crystalline, showing its characteristic prismatic development, but more commonly it is fine-grained and may closely resemble galena. When examined in polished section the fine-grained variety is seen to be a mosaic of stibnite. Some large angular fragments of stibnite are surrounded by a fine-grained mosaic of the same mineral, strongly suggesting that after the formation of the large crystals movement took place, breaking the crystals; and then later this breccia was cemented with later stibnite.

\section{OXIDATION AND ENRICHMENT}

The upper portions of all the veins show some evidence of oxidation, iron staining is prevalent, cavities have been formed by the removal of metallic minerals, and oxidation minerals such as scor- 


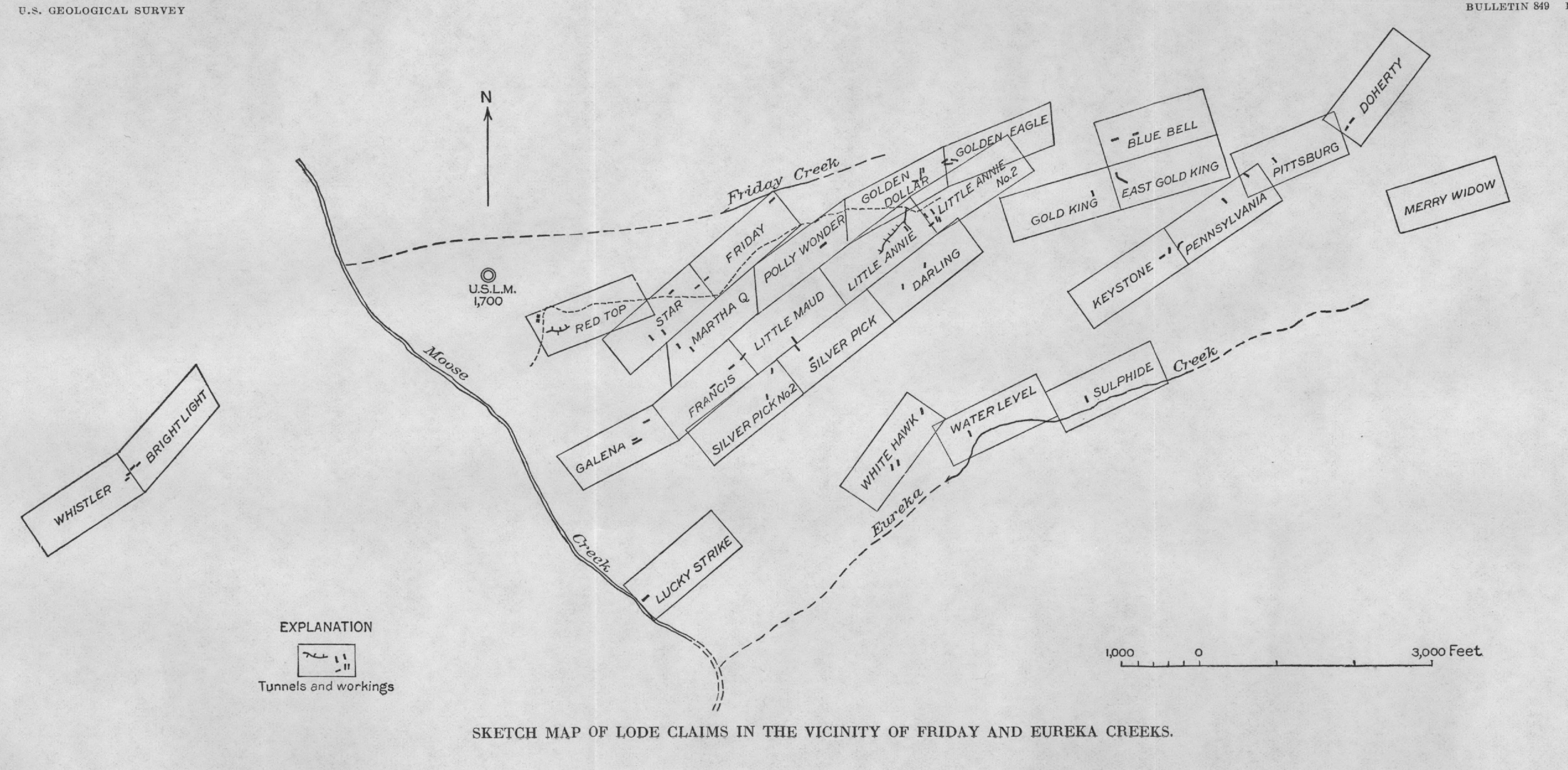



U.S. GEOLOGICAL SURVEY

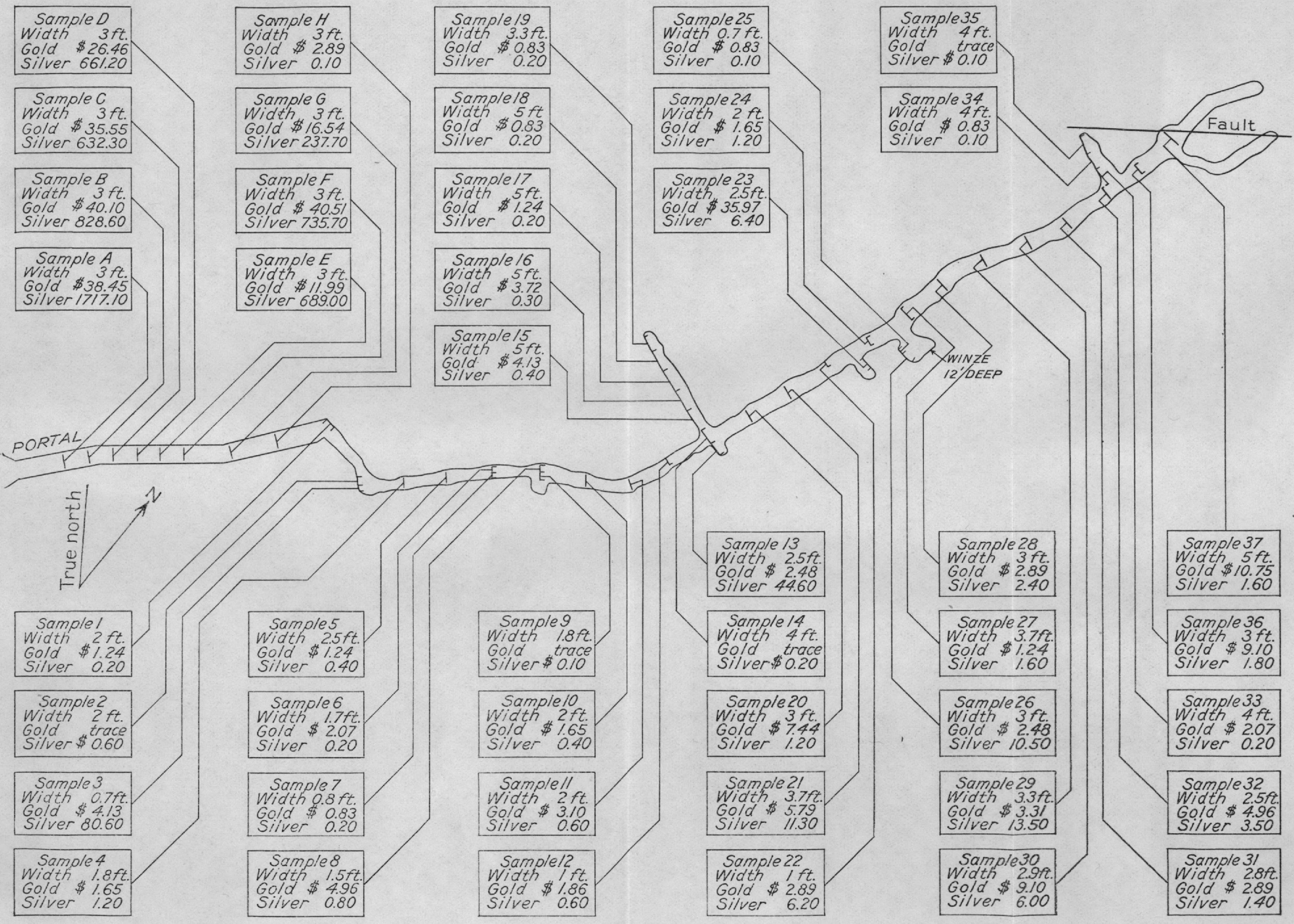

ASSAY MAP OF RED TOP TUNNEL. 

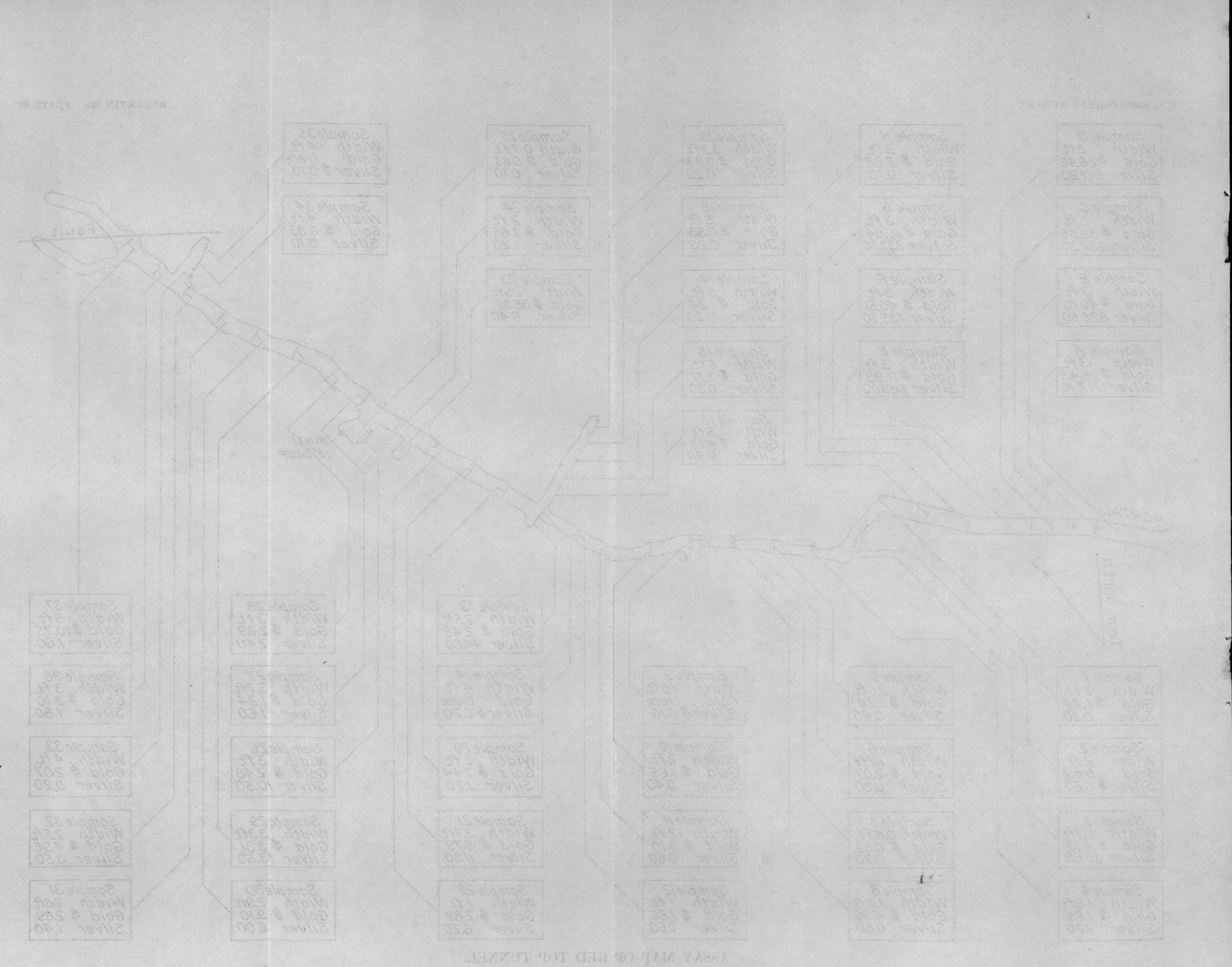
odite, cerusite, malachite, stibiconite, and kermesite have been formed. The process has not been active, however, as most of the original readily oxidizable sulphide minerals still remain. Furthermore, the frozen condition of the ground does not allow free circulation of downward-moving oxygenated water. The presence of melanterite, a highly soluble and readily oxidized mineral, in the veins near the surface is excellent proof of this. Hence, though some oxidation has taken place in the upper few feet of the veins, it appears to have been neither extensive nor deep in this district. As gold is practically insoluble and silver relatively so, these metals are left behind or migrate only a short distance in the process of oxidation, so the removal of other material from the vein near the surface leaves a product relatively richer in gold and silver. Such negative enrichment has probably taken place in the upper few feet of the veins in the Kantishna district.

No silver-bearing minerals that are formed only under surface conditions have been found in the veins of the district. The absence of extensive downward movement of ground water makes it seem unlikely that surface enrichment of the veins has taken place, either during the present geologic epoch or in the Pleistocene, when glaciation prevailed. The absence of mineralogic and textural evidence of enrichment makes it seem improbable that any significant enrichment has taken place. There is no reason, therefore, to expect that the gold and silver content of the veins should diminish rapidly in depth.

\section{GENESIS OF ORE}

The distribution of the veins in close proximity to igneous intrusives indicates that the veins were formed by solutions given off by the magma that furnished the dikes. The solutions filled openings in the schist produced by faulting, and movement continued throughout the period of mineralization.

The mineral association, as well as the structure and texture of the veins, clearly places the deposits in the mesothermal or intermediate-temperature group of Lindgren. ${ }^{23}$ The clinozoisite, scheelite, and cassiterite-if the cassiterite found in the placers is derived from these veins-indicate an affiliation with the high-temperature deposits, whereas the stibnite veins show lower-temperature relations. It would seem, therefore, that although the major mineralization took place at intermediate temperatures, the initial temperatures were somewhat higher and the end temperature slightly lower than those characteristic of mesothermal conditions. The quartz veins of the Eureka and vicinity area are related in type to the gold quartz

Lindgren, Waldemar, Mineral deposits, 3d ed., pp. 598-717, 1928.

179399-33-3 
veins of the Sierra Nevada, ${ }^{24}$ and the galena-tetrahedrite-carbonate weins of the Kantishna district are similar to the Wood River type of silver-lead veins. ${ }^{25}$ Unlike mesothermal deposits, which usually occur in or near intrusive bodies such as stocks or batholiths, the veins are found near dikes which are neither very wide nor very long (p. 348). This anomalous fact might be explained if the dikes are apophyses occurring along the flank of a large batholith. No direct evidence, however, has been observed either for or against this interpretation.

\section{ECONOMIC FACTORS}

Most of the economic factors related to the development of mines in the Kantishna district are largely dependent on transportation. As the completion of the McKinley Park road (p. 336) will basically change the facility and cost of transportation into the Kantishna within a few years, existing conditions are of only current significance, and therefore these factors will be discussed here only briefly. Formerly shipments of ore were hauled on wagons to Roosevelt and taken by boat from Roosevelt to Nenana. The cost of hauling ore from Friday Creek to Roosevelt was $\$ 32$ a ton, and the charge from Roosevelt to Nenana was $\$ 25$ a ton. If there were any considerable tonnage the cost from Roosevelt to Nenana could be somewhat lessened. Labor is very scarce, and the customary wage is $\$ 7$ a day if board and lodging are furnished or $\$ 8$ a day if the man provides his own subsistence. Except for the few cabins owned and occupied by the placer miners there are practically no buildings in the area. The nearest source of timber is on Bear Creek, a distance of 10 to 15 miles over ground that is practically impassable during summer. Here an abundant supply of spruce suitable for mining purposes is available. On upper Moose Creek lignite beds of a fair grade as much as 10 feet thick are exposed, and a considerable tonnage of lignite suitable for local fuel could be mined without much difficulty. Good water is abundant. Moose Creek could furnish water sufficient for any ordinary operations likely to take place. The canyon of McKinley Fork, about 10 miles to the west, is open the year round and might offer water-power possibilities.

\section{MINES AND PROSPECTS}

QUIGLEY HILL

Quigley Hill is the ridge lying between Friday and Eureka Creeks and bounded on the west by Moose Creek. At its east end it attains a maximum elevation of 3,100 feet, but its general elevation is 2,900 feet, or about 1,300 feet above Moose Creek. The

${ }^{24}$ Lindgren, Waldemar, op. cit., pp. 616-629.

$\approx$ Idem, pp. 642-645. 
location and general form of the hill are clearly shown on the topographic map (pl. 28). The systematic prospecting of J. B. Quigley, after whom the hill was named, has uncovered both quartz and galena lodes from which over 1,000 tons of ore has already been mined and shipped. Most of the proved mineral ground on this hill has been patented, some 25 patents having been issued, most of which are owned by Mr. Quigley. (See pl. 29.) In general, the hill is smooth and is covered with soil and rock debris; but its south slope is largely covered by alder bushes. Outcrops are mostly confined to a few ledges along the creeks and to the knobs on the ridge tops. The bedrock of the north slope of the hill has been mapped as dominantly limestone and chlorite schist. (See pl. 28.)

\section{RED TOP}

The Red Top claim (J. B. Quigley, owner) is regarded as one of the most promising claims in the district. It lies near the west end of Quigley Hill just south of Friday Creek. (See pl. 29.) The long dimension of the claim trends N. $67^{\circ}$ E., roughly parallel to the trend of the ridge. Open cuts, shafts, tunnels, and winzes have exposed the Red Top vein for a total distance along the strike of 300 feet and for a vertical distance down the dip of 150 feet.

The portal of the main tunnel, the principal as well as the most westerly opening, is 100 feet east of the western boundary of the claim. The tunnel extends for 300 feet in a winding course along a shear zone. Short crosscuts were driven from it, and two winzes connect the tunnel to two stopes, a lower stope whose floor is 32 feet below the tunnel level and an upper stope where the floor is 12 feet below the tunnel level. The upper stope was mined to the surface, and both stopes were connected with the surface by a shaft. (See fig. 45.) Ore amounting to 102 tons was mined from these stopes in 1923, 80 percent of which ran equal to or better than 0.90 ounce of gold and 214.4 ounces of silver to the ton.

About 170 feet east of the portal along the strike of the vein and 86 feet higher up the hill is a 50-foot shaft from which drifts have been driven at the 25 -foot level and the 50 -foot level, crosscutting the vein. About 70 feet farther east and 24 feet up the hill is an open cut exposing the vein, which there has a width of 22 feet. Ore amounting to 28 tons was taken from the shaft and open cut. Though other work has been done on the claim, it had caved and was inaccessible in the summer of 1931.

Limestone crops out on the Red Top claim, and the limestone chlorite schist is found throughout the claim. The vein, which strikes N. $60^{\circ}$ E. and dips at a steep angle to the southeast, is of the fissure-vein type, thinning and thickening considerably along 
both the strike and dip; the maximum width exposed is 22 feet. A thin selvage of gouge separates the hanging wall from the schist, but along the footwall small stringers of quartz run through the contiguous schist. The vein is predominantly quartz, though it contains some large stringers and lenses of almost solid sulphide, such as the lens that was mined below the main tunnel. The sulphides are

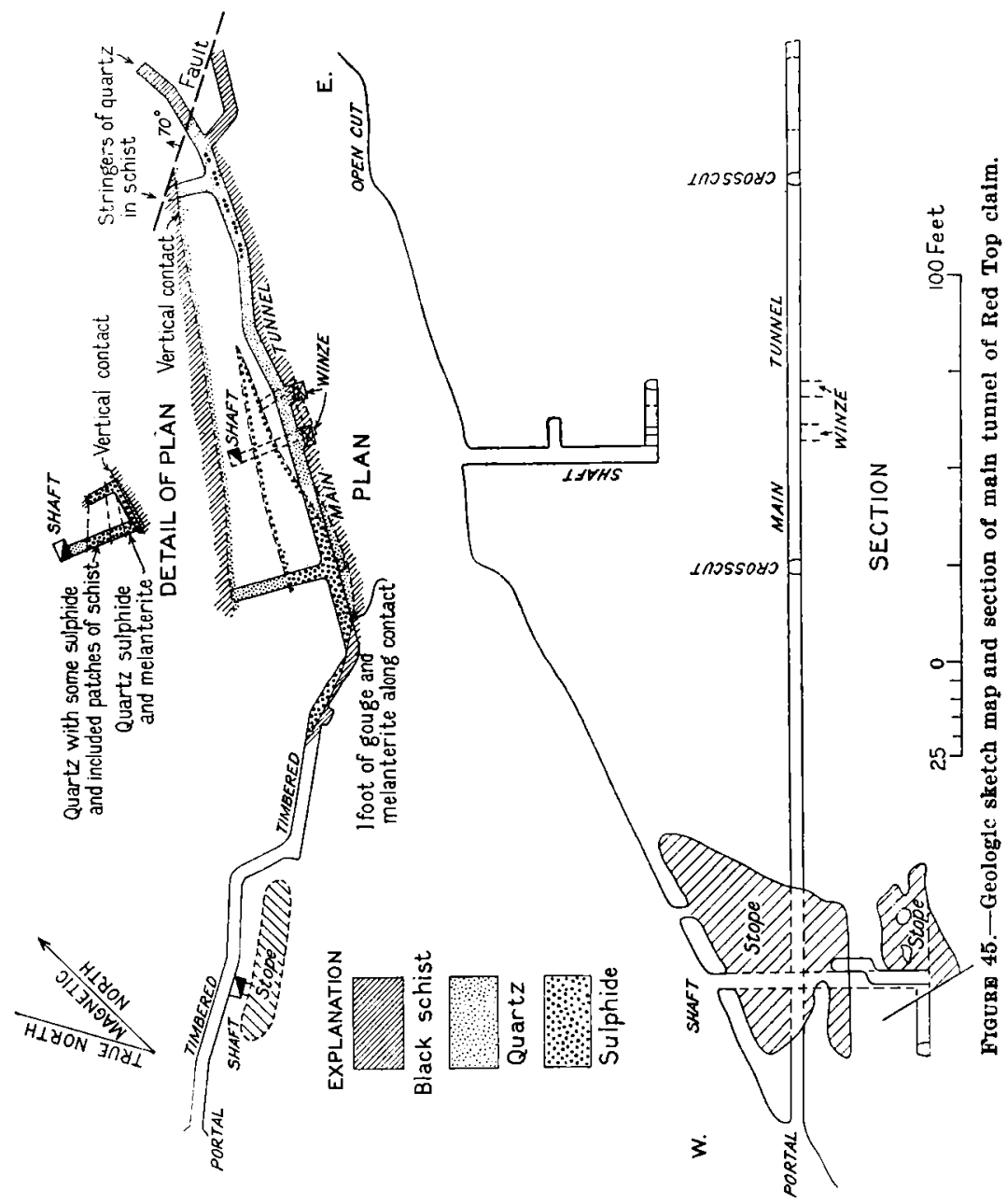

arsenopyrite, pyrite, galena, sphalerite, tetrahedrite, jamesonite, and pyrargyrite. In some places the sulphide mineral is largely arsenopyrite, with lesser amounts of the other sulphides, but in other places it is almost pure galena, with some tetrahedrite, as was much of the material mined from the lower stopes.

Smelter returns for the ore shipped from the Red Top mine (p. 364) show a direct relation between the arsenic and antimony 
content and the gold and silver, the highest precious-metal content always occurring where the arsenic is highest. Furthermore, the lowest precious-metal content is associated with the largest lead content and the lowest arsenic content. This shows conclusively that the precious metals are closely associated with arsenopyrite, tetrahedrite, and jamesonite and that these minerals are not generally abundantly associated with the galena. Some of the sulphide masses are fairly large; the one mined, although according to Mr. Quigley the boundaries of the sulphides were not reached, was 27 feet along the strike, 4 feet thick, and 68 feet wide down the dip. Much melanterite occurs in the upper shaft, and Davis ${ }^{26}$ reports sulphur in one of the trenches. Though these are oxidation minerals, there seems to be little evidence of enrichment. The vein has been cut off at the east by a fault that strikes N. $87^{\circ} \mathrm{W}$. and dips $70^{\circ} \mathrm{S}$. The vein has not been found beyond the fault, but by drifting along the footwall side of the fault to the west the continuation of the vein should be picked up.

In the trench the vein is 22 feet wide and consists of quartz carrying galena. Assays of 5-foot samples starting at the footwall and crossing the vein are given below:

\begin{tabular}{|c|c|c|c|c|c|c|c|}
\hline Sample no. & $\begin{array}{c}\text { Distance } \\
\text { fromf } \\
\text { footwall } \\
\text { (feet) }\end{array}$ & $\begin{array}{l}\text { Gold } \\
\text { (ounce } \\
\text { to the } \\
\text { ton) }\end{array}$ & $\begin{array}{l}\text { Silver } \\
\text { (ounces } \\
\text { to the } \\
\text { ton) }\end{array}$ & Sample no. & $\begin{array}{c}\text { Dlstance } \\
\text { from } \\
\text { tootwall } \\
\text { (feet) }\end{array}$ & $\begin{array}{c}\text { Gold } \\
\text { (ounce } \\
\text { to the } \\
\text { ton) }\end{array}$ & $\begin{array}{l}\text { Silver } \\
\text { (ounces } \\
\text { to the } \\
\text { ton) }\end{array}$ \\
\hline $85-10$. & $\stackrel{0-5}{5-10}$ & $\begin{array}{r}0.02 \\
.26\end{array}$ & $\begin{array}{r}1.30 \\
49.40\end{array}$ & 93 & $\begin{array}{l}10-15 \\
15-22\end{array}$ & $\begin{array}{r}0.04 \\
.10\end{array}$ & $\begin{array}{l}2.60 \\
2.40\end{array}$ \\
\hline
\end{tabular}

On the lower level of the shaft workings the following assays were obtained :

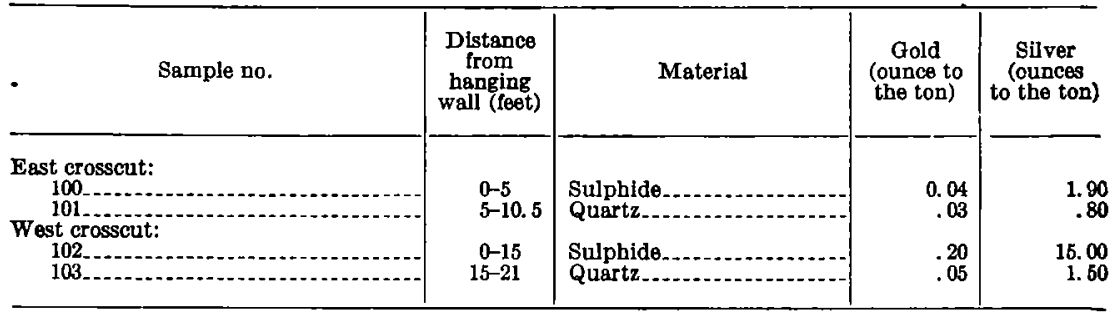

The assays obtained by J. A. Davis from the main level are shown in plate 30 . Samples $A$ to $H$ were taken by the owner. The silver was calculated as worth $\$ 1$ an ounce.

The smelter returns for all the ore shipped from the stoped part of the Red Top vein show that 80 percent of the ore ran equal to

${ }^{26}$ Davis, J. A., Annual report of the mine inspector to the Governor of Alaska for 1922, p. 12 . 
or better than 0.90 ounce of gold and 214.40 ounces of silver to the ton. The richest ore and poorest ore yielded the following assays:

\begin{tabular}{|c|c|c|c|c|c|}
\hline & Richest & Poorest & & Richest & Poorest \\
\hline 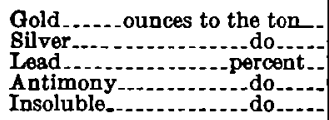 & $\begin{array}{r}2.53 \\
325.15 \\
2 . \\
1.6 \\
41.0\end{array}$ & $\begin{array}{r}0.22 \\
128.00 \\
50.6 \\
.6 \\
6.8\end{array}$ & $\begin{array}{l}\text { Iron } \\
\text { Zinc } \\
\text { Sulphur } \\
\text { Arsenic_- }\end{array}$ & $\begin{array}{r}11.9 \\
0 \\
10.8 \\
4.6\end{array}$ & $\begin{array}{r}6.3 \\
9.5 \\
19.1 \\
2.5\end{array}$ \\
\hline
\end{tabular}

It is clear from the assays of the samples from the tunnels and open cut that throughout much of the vein at those places the ore carries less than $\$ \tilde{5}$ in gold and 1 or 2 ounces in silver to the ton but that in places there are shoots of high-grade ore.

\section{POLLY WONDER}

The Polly Wonder lies to the east and along the general trend of the Red Top vein, on the north slope of Quigley Hill. (See pl. 29.) On this property an open cut exposed a mineralized quartz vein 7 feet wide. A sample taken across the vein assayed 0.12 ounce in gold and 2.20 ounces in silver to the ton. Joseph Dalton owns a third interest in the claim, and the remainder belongs to J. B. Quigley.

\section{LITTLE ANNIE}

The Little Annie claim, one of the three claims in the district from which ore has been shipped, is situated on the north slope of Quigley Hill. (See pl. 29.) Two veins have been found on the claim-the principal vein, on which most of the work has been done, and a small secondary vein from which some ore has been mined and shipped. The smaller vein, which lies to the south of the main vein, was opened by a tunnel about 170 feet long and by a shaft and stope. At the time the writer visited the property in 1931 these workings were filled with solid ice, and as no maps had been made of them little specific information could be obtained. Davis ${ }^{27}$ states that the strike of the vein is N. $20^{\circ} \mathrm{E}$. and its dip $65^{\circ}-70^{\circ} \mathrm{SE}$. The small vein trends toward the main vein, though their dips are parallel. The ore is reported to have been almost solid galena with some sphalerite and a little tetrahedrite. The gangue where present was either siderite or calcite. It is further stated that rich ore rarely continued to a depth of more than 60 feet from the surface.

About 700 tons of lead-silver ore was shipped from the south vein in 1920 . The ore averaged approximately 25 percent of lead and 0.16 ounce of gold and 130 and 150 ounces of silver to the ton. Paul

${ }^{27}$ Davis, J. A., op. cit., p. 128. 
Hopkins states that the gross return on 438.6 tons of the ore was $\$ 78,546.93$, or an average of $\$ 179.08$ a ton. At that time silver sold for $\$ 1$ an ounce.

Five trenches roughly 50 feet apart have uncovered the main vein at the surface for a length of 210 feet. In this distance the vein ranged from a maximum width of 32 feet to a minimum of 15 feet. The same vein, cut in depth by an adit 85 feet long trending S. $40^{\circ}$ W., has been opened by a drift 510 feet long and 11 crosscuts spaced at intervals of about 40 feet. (See pl. 31.) This level is 90 feet below the highest point of the vein as shown in the trenches at the surface. The vein strikes N. $59^{\circ}$ E., dips $58^{\circ}-74^{\circ}$ S., and seems to be lenticular in outline, ranging in width from 3.5 feet at the east end to 23 feet at a point 160 feet to the west and then pinching to a width of 9 feet. The vein, which occurs in the schist, is of the fissure type and has a smooth hanging wall; the footwall is less definite, containing in places numerous small stringers of quartz. Furthermore, patches and horses of schist occur within the vein, and these are in places so cut by small quartz veinlets as to be largely composed of quartz. Movements along transverse faults that have a northwesterly strike have offset the vein a few feet, and movements along planes parallel to the vein have fractured, grooved, and slickensided the quartz.

The vein material is principally shattered quartz, usually ironstained but where unweathered consisting of broken white quartz with small cavities of limonite. In some places two generations of quartz are evident, the first consisting of angular fragments of quartz cemented by later quartz. As a rule sulphides are sparingly present, only small crystals of pyrite and arsenopyrite being seen scattered through the quartz. In some places, however, patches of galena and sphalerite from a fraction of an inch to about an inch in diameter are found in the quartz, and a few veinlets of quartz and galena occur within the main quartz vein. When such patches of galena or sphalerite are examined in polished sections they are found to contain sphalerite, galena, pyrite, arsenopyrite, chalcopyrite, and tetrahedrite. Gold occurs free in small specks.

The vein shows no true gossan, for though it is iron-stained and much of the arsenopyrite is completely oxidized to limonite the galena is fresh and unoxidized. Galena is notably resistant to weathering, but if the vein had been subjected to weathering for a prolonged period and the products were not removed by erosion it should be at least partly oxidized. The absence of oxidation of the galena therefore seems to preclude the probability of enrichment below, and this leads to the conclusion that the vein has not been materially enriched either above the water table by the removal of 
material or below the water table by addition of material of supergene origin. Stated otherwise, as rich ore should be found in depth as has already been opened up.

The west end of the main drift is still in the vein, but if the vein maintains its present strike it will come through to the surface in 100 feet. Surface trenching along the eastward projection of the vein has failed to uncover it, but though possibly it may have been somewhat offset by faulting, its continuation will probably be found in the vicinity.

The vein as exposed in the tunnel and trenches was sampled. Channel samples were taken across the vein at 10 -foot intervals, and 5-foot samples were taken along the walls of the crosscuts. Plate 32 is an assay map of the tunnel. With the exception of sample 33, which gave an unusually high assay, the average of all the samples taken was 0.10 ounce in gold and 2.10 ounces in silver to the ton for a length of 468 feet along the strike and an average width of 17 feet. The trench samples are listed below. It is possible that the vein has been slightly enriched at the surface by weathering.

Assays of trench samples from Little Annie claim

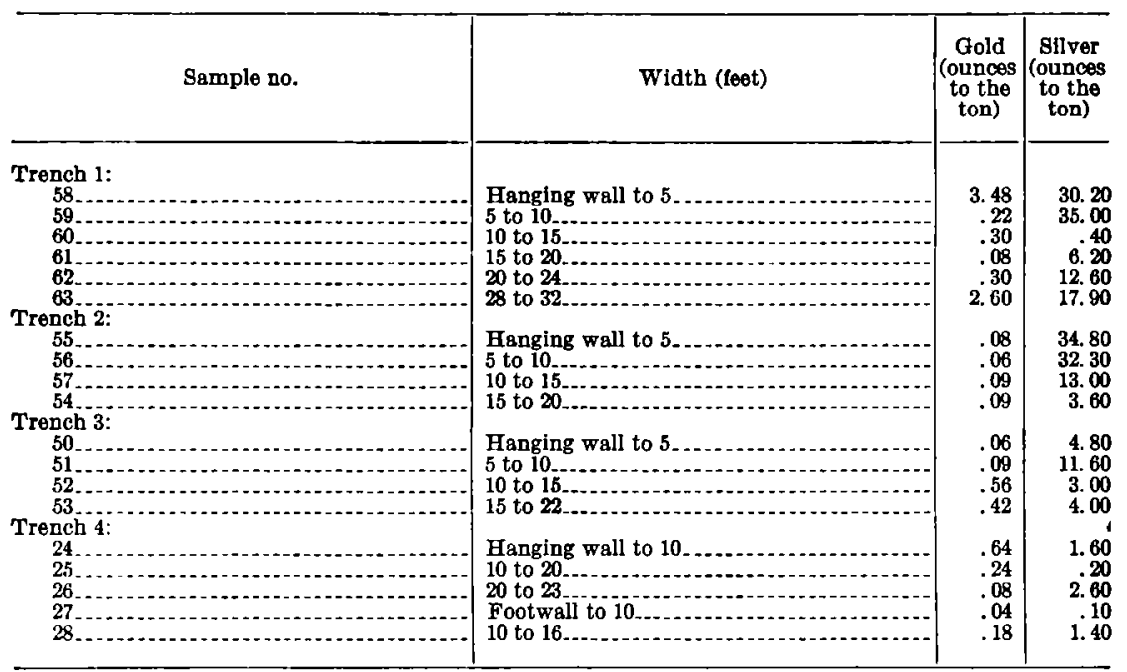

GOLD DOLLAR AND GOLDEN EAGLE

The adjoining Gold Dollar and Golden Eagle claims lie at the head of Friday Creek and are contiguous to the Little Annie and Little Annie No. 2 claims. About 500 tons of high-grade silver-lead ore was mined from the Gold Dollar in 1921. The smelter returns show that the ore averaged more than $\$ 70$ to the ton, the silver running as 


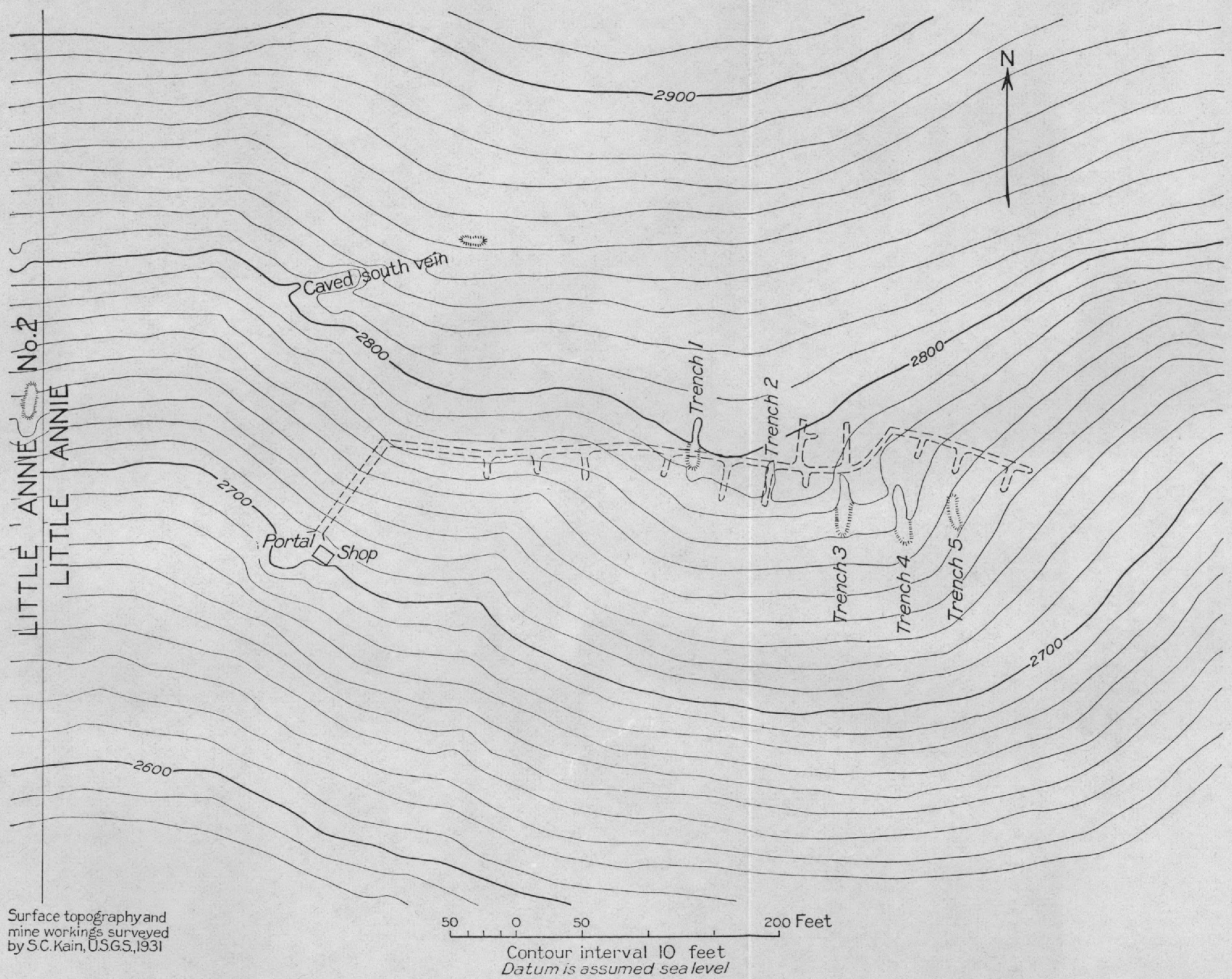

CONTOUR SKETCH MAP OF LITTLE ANNIE CLAIM, SHOWING TUNNEL. 



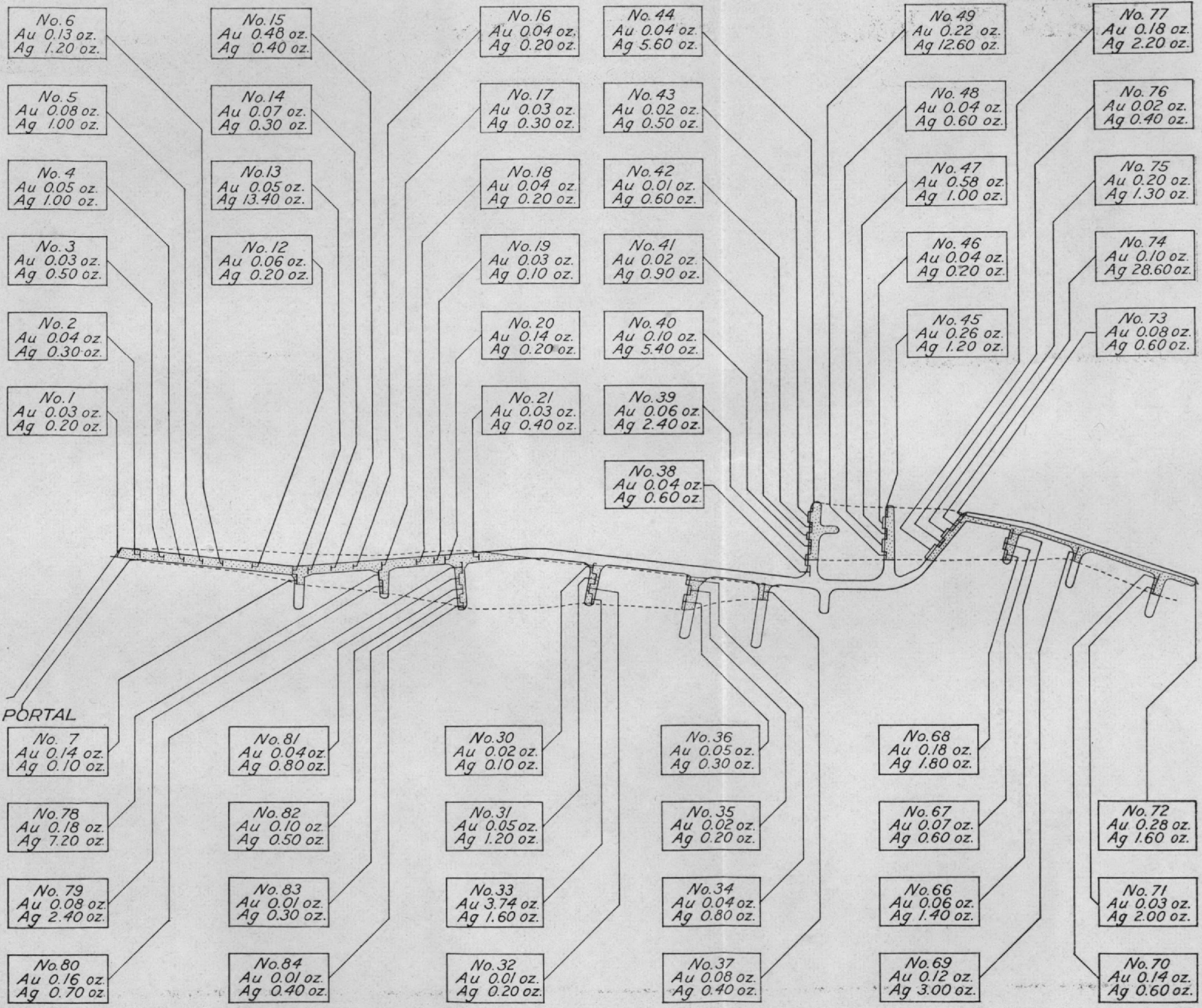

ASSAY MAP OF LITTLE ANNIE TUNNEL. 


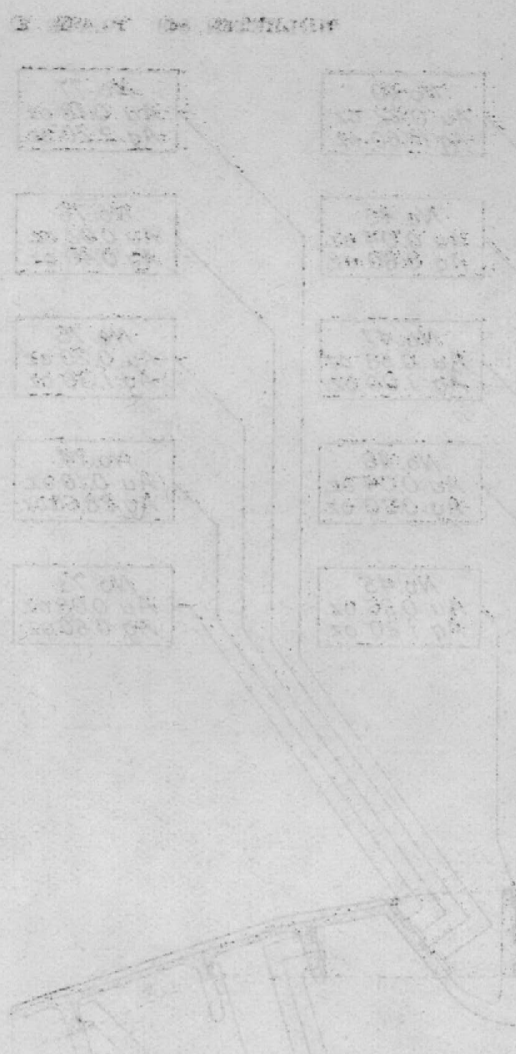

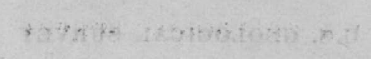
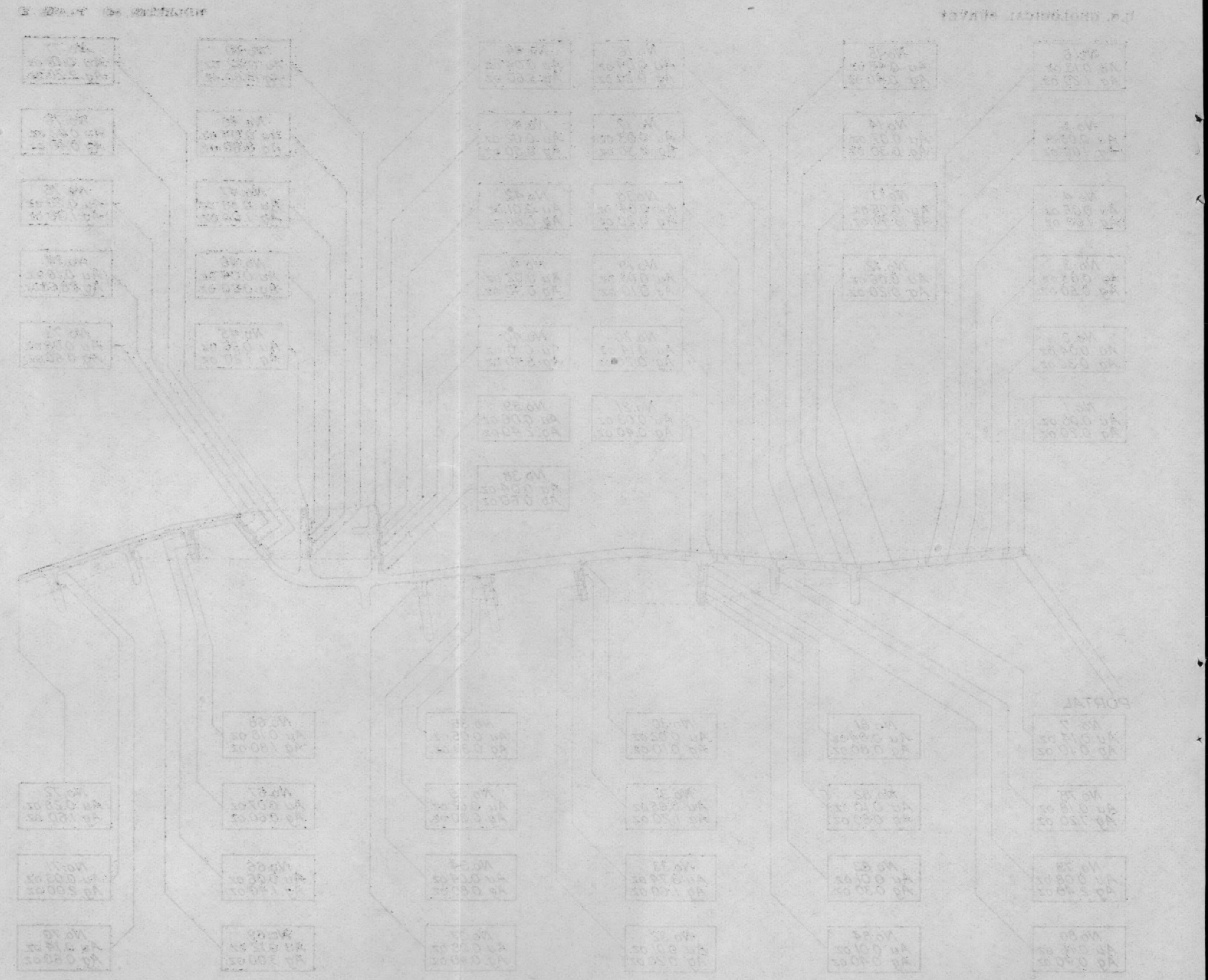
high as 152 ounces and the gold as high as 0.18 ounce to the ton. The workings are now completely caved and inaccessible. According to Davis ${ }^{28}$ the vein on the Gold Dollar averaged 3 to 4 feet in width and contained galena, sphalerite, tetrahedrite, and stromeyerite. The vein, which strikes $\mathrm{N}$. $65^{\circ} \mathrm{E}$. and dips $75^{\circ} \mathrm{S}$., was developed by a shaft 38 feet deep and a tunnel 250 feet in length. Mr. Davis described the workings on the Golden Eagle as follows:

At discovery cut, near the west end line of the Gold Eagle claim, a vein approximately 3 feet wide was disclosed containing galena, pyrite, sphalerite, and the oxidation products of these minerals. The sulphides carry high values in silver. A tunnel was started on the east side of the small draw to intersect this vein and follows a crushed and slickensided zone for 60 feet along a course N. $70^{\circ} \mathrm{E}$. It then swings to the north for an additional $60 \mathrm{feet}$, where it intersects the vein and follows it for 30 to 40 feet along a course $\mathrm{N}$. $65^{\circ} \mathrm{E}$. The vein dips $75^{\circ} \mathrm{SE}$. The vein in the tunnel, which is chiefly quartz, does not contain as many sulphides as are found in the surface cut. In the tunnel these are confined to a band 8 or 10 inches wide near the footwall. Three or four tons of high-grade ore, valued at $\$ 170$ per ton, were mined from the surface cut by the lessee in 1920 .

\section{LUCKY STRIRE}

The tunnel and open cuts on the Lucky Strike claim were caved and completely inaccessible in 1931 . Davis ${ }^{28}$ gives the following description:

Two veins have been discovered on the Lucky Strike claim in the bluff overlooking Moose Creek. A tunnel has been driven along the strike of one of these veins, which is $\mathrm{N}$. $59^{\circ}$ E. The vein, which dips $84^{\circ} \mathrm{S}$., is exposed for 20 feet above the tunnel and shows at least 6 feet of quartz between schist walls. The hanging wall is highly silicified. A sample of this vein next the footwall, consisting of highly mineralized quartz and thought to be the richest portion, shows 0.04 ounce of gold and 6.40 ounces of silver per ton. A sample of the next 3 feet of the vein shows 0.05 ounces of gold and 10 ounces of silver per ton. The vein is reported to carry valuable minerals beyond this width, but a sample could not be obtained.

The second vein has been exposed in two open cuts about 40 feet apart and lying 125 feet north of the tunnel just mentioned. They show a strong quartz vein, well mineralized, and probably about 8 feet wide, although the cuts were so badly caved that the width could not be accurately determined, nor could a representative sample be secured. A number of pieces of vein matter that were broken off at random assayed 0.04 ounce of gold and 1.40 ounces per ton in silver. The samples were taken by Mr. John Gross, metallurgist of the Bureau of Mines.

\section{GALENA}

The Galena claim lies near the west end of Quigley Hill about 2,000 feet south of the Red Top, and is adjoined by the Francis claim on the east. The principal developments on this claim are a tunnel near the discovery stake and an open cut about 300 feet to the northeast. At the time of visit the tunnel and the open cut were partly

${ }^{28}$ Davis, J. A., op. cit., p. 124. 
caved, so that much of the information given is derived from the report of Davis. ${ }^{30}$

The tunnel was driven through schist country rock for a distance of 30 feet, to a vein that strikes N. $45^{\circ}$ E. and dips $58^{\circ} \mathrm{SE}$. The vein was followed for 30 feet, and a winze was sunk to a depth of 20 feet. The vein, where now accessible, is about 2 feet wide but is reported to have attained in places a width of 8 or 9 feet and to have consisted of broken quartz containing galena, arsenopyrite, zinc blende, and tetrahedrite. On the hanging wall the vein has a sharp contact, being separated from the schist by about 1 foot of gouge, but on the footwall its contact is gradational, the schist being replaced by quartz containing some sulphides.

The open cut northeast of the tunnel shows a quartz vein about a foot in width containing tetrahedrite and chalcopyrite. The strike of this vein is $\mathrm{N} .45^{\circ} \mathrm{E}$. and the dip nearly vertical. Between 50 and 100 tons of ore derived partly from the tunnel and partly from the open cut has been mined and shipped to a smelter in California.

FRANCIS

- Developments on the Francis claim consist of a tunnel along the strike of the vein 70 feet in length, the first 40 feet of which is timbered, and a series of open cuts on the surface extending along the strike of the vein, which is $\mathrm{N}$. $55^{\circ} \mathrm{E}$. The vein matter in the tunnel is chiefly white quartz carrying a few scattered crystals of pyrite and some gold. The vein changes from a nearly solid body of quartz 1 foot wide at the end of the timber to a network of quartz stringers cutting the schist at the breast. A series of samples gave the following assays:

\begin{tabular}{|c|r|r|r|}
\hline $\begin{array}{c}\text { Distance } \\
\text { from } \\
\text { portal } \\
\text { (feet) }\end{array}$ & $\begin{array}{c}\text { Width } \\
\text { (inches) }\end{array}$ & $\begin{array}{c}\text { Gold } \\
\text { (ounce to } \\
\text { the ton) }\end{array}$ & $\begin{array}{c}\text { Silver } \\
\text { (ounce to } \\
\text { the ton) }\end{array}$ \\
\hline 50 & 12 & 0.02 & $\begin{array}{r}0.80 \\
.04\end{array}$ \\
60 & $\begin{array}{r}.70 \\
.60\end{array}$ \\
\hline 70 & 12 & .02 & .60 \\
\hline
\end{tabular}

As the open cuts were filled with material that had caved from the sides, nothing regarding the character of mineralization in them could be determined.

\section{SILVER PICK AND IITTLE MAUD}

The Silver Pick claim parallels the Little Maud and Little Annie claims and is contiguous to them on the south. (See pl. 29.) These

${ }^{30}$ Davis, J. A., op. eit., p. 123. 
claims are situated on the top of Quigley Hill near its west end. About 200 feet east of the western boundary of the claims two veins that strike $\mathrm{N}$. $35^{\circ} \mathrm{E}$. have been uncovered at the surface by open cuts. The larger vein is in a shear zone about 10 feet wide made up of crushed iron-stained quartz with some scattered bunches of galena. The second vein, exposed in an open cut about 175 feet to the southwest, is 8 feet wide and assayed 0.04 ounce of gold and 17.60 ounces of silver to the ton. A straight adit 150 feet long trending S. $34^{\circ} \mathrm{E}$. was driven to cut the veins. At 50 feet from the portal it encountered a crushed quartz zone 5 feet wide, containing numerous bunches of galena and some pyrite and dipping about $65^{\circ} \mathrm{NW}$. The remainder of the tunnel is in schist cut by numerous stringers of quartz an inch or two thick.

When Capps ${ }^{31}$ visited the district in 1916 , the tunnel was 188 feet long, and a second vein was exposed in the face of the tunnel. Capps describes this vein as follows:

Near the breast of the tunnel the main vein consists of a 13-foot zone striking N. $35^{\circ} \mathrm{E}$. and dipping $67^{\circ} \mathrm{SE}$. and is therefore approximately parallel in strike with the vein already described but lies 130 feet northeast of it. This zone consists of 1 foot of calcite on the footwall and 12 feet of quartz and schist, more or less sheeted, the quartz predominating in bulk over the country rock. Little galena is seen in the tunnel, but it is abundant along the surface crop of the vein. The whole zone is brecciated and leached, and large open cracks extend from the tunnel to the surface. Pyrite. arsenopyrite, and small amounts of galena and sphalerite were observed, and along some of the cracks deposits of a soluble salt, which on analysis proved to be the iron sulphate melanterite, were found.

Just north of the boundary of the Silver Pick claim on the Little Maud claim a vein striking roughly $\mathrm{N}$. $55^{\circ} \mathrm{E}$. has been crosscut by two trenches. The vein is 13 feet wide, consists predominantly of quartz with some large areas of fine-grained galena in which are threads of chalcopyrite. Samples across the vein gave the following returns :

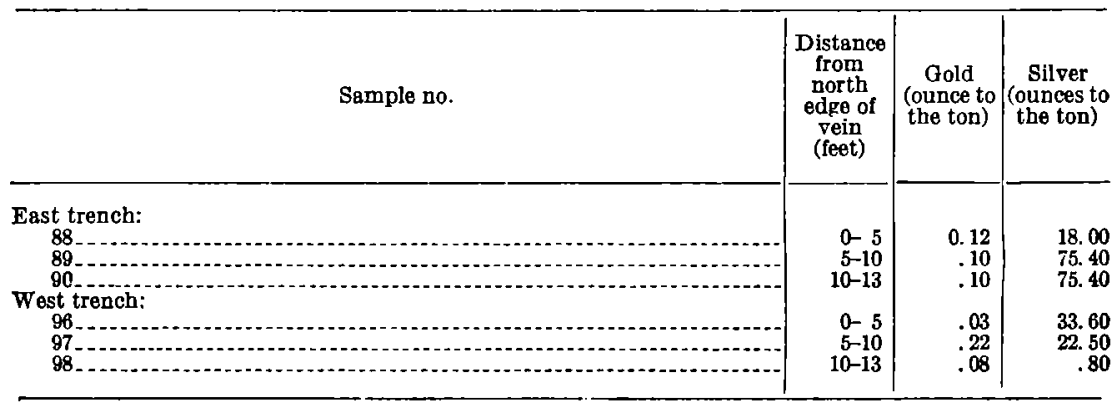

31 Capps, S. R., The Kantishna region, Alaska : U.S. Geol. Survey Bull, 687, p. 105, 1919. 


\section{PENNSYLVANIA AND KEYSTONE}

The workings on the Pennsylvania and Keystone claims were so badly caved and filled that they were inaccessible in 1931. Davis ${ }^{32}$ gives the following description of the veins on these claims:

There are two principal veins on the Pennsylvania claim, which have been named Pennsylvania and Keystone by the owner.

The Pennsylvania vein crosses the west end line of the claim (which lies at the bottom of Iron Gulch) about 100 feet north of the center and extends up the east slope toward the Pittsburgh claims. The strike of the vein is N. $65^{\circ} \mathrm{E}$. with a dip of $85^{\circ} \mathrm{S}$., and it has been traced for over 500 feet by a series of open cuts spaced at approximately 100 feet intervals. Although there is a gap of about 1000 feet which has not been prospected yet, hence the continuity is not absolutely established, it is quite likely that this vein is the same one that is exposed in the discovery cut on the Pittsburgh claim. The vein matter is quartz containing some pyrite and calcite, and free gold can be panned from samples taken along the outcrop.

The Keystone vein crosses the west end line of the claim at a point 100 feet south of the Pennsylvania vein. It has a strike of $\mathrm{N}, 50^{\circ} \mathrm{E}$. with a dip of $60^{\circ} \mathrm{S}$. and extends up the hill toward the northeast corner of claim, intersecting the Pennsylvania vein about 400 feet from the west end line. It has been traced along the surface for more than 1,200 feet by 20 open cuts on the outcrop. The vein matter is chiefly quartz containing a considerable quantity of pyrite and arsenopyrite and some sphalerite and galena. It varies from 4 to 6 feet in width. A tunnel starting near the western end line of the claim has been driven for 50 feet along the hanging wall of the vein, and a shaft was sunk to a depth of 30 feet at a point near the intersection with the Pennsylvania vein. A sample taken by $\mathrm{Mr}$. Gross across 14 inches of vein matter in the face of the tunnel assayed 1.6 ounces of gold and 1.60 ounces of silver per ton. Several ounces of finely crystallized gold were obtained by panning in a small open cut 60 feet east of the portal of the tunnel. A sample taken in the shaft by the writer gives the following assay: Gold, 0.96 ounce per ton, and silver, 0.20 ounce per ton.

Both the Keystone and Pennsylvania veins have been traced by open cuts for 300 or 400 feet on this claim. There is a third vein which outcrops near the east end line of the claim between the other two veins and intersects both of them. The strike of this rein is $\mathrm{N}$. $30^{\circ} \mathrm{E}$., and it has a steep dip. It is developed by a tunnel which is 50 feet long and by several open cuts on the surface. The vein matter is quartz carrying galena and some pyrite. The vein is 3 feet wide at the portal of the tunnel but narrows to 12 inches at the face. Some of the assays of weathered quartz taken from the surface cuts show high values in gold, while others show but a trace, indicating that the rleposit is extremely "spotty."

\section{BANJO}

The Banjo claim is located on Lucky Gulch, a small southwardflowing tributary of Eureka Creek. (See pl. 28.) The surface is strewn with quartz carrying free gold. J. B. Quigley, the owner, has dug a series of open cuts to locate the vein in place, but in all of them the vein uncovered was in a block that does not appear to be

a2 Davis, J. A., op. cit., pp. 129-130. 
in place. A tunnel driven 60 feet into the hill at an elevation of 3,100 feet traversed only black graphitic schist.

DAMON AND PYTHIAS AND MERRT WIDOW

Southeast of the Banjo claim and at about the same elevation are the Damon and Pythias and Merry Widow claims of William Taylor. The only accessible working, a tunnel, follows a quartz vein for 90 feet to a point where the vein is cut off by a fault that strikes $\mathrm{N} .52^{\circ} \mathrm{W}$. and dips $30^{\circ} \mathrm{SW}$. The tunnel was continued through the fault and 30 feet southeastward but failed to disclose the continuation of the vein. The vein is composed of fractured quartz sparsely flecked with sulphide. The vein strikes N. $84^{\circ}$ E. and is about 7 feet wide.

\section{GLACIER CREEK}

Glacier Creek and its tributaries, Yellow Creek and Twenty-two Gulch, have yielded considerable placer gold, and, as on the other auriferous creeks, considerable galena is found in the concentrates. Most of the prospecting for lodes has been done by surface trenching, but these trenches are now so completely caved that they show almost nothing as to the geology of the neighborhood. Iron-stained quartz, with numerous cavities, occurs both as float and croppings. at intervals along the divide between the Glacier Creek Basin and those of Eureka and Dry Creeks. The float occurs in a band that strikes a few degrees north of east and conforms to the general trend of the schistosity. A series of open cuts across the quartz croppings was dug some time ago by William Taylor, but as far as could be ascertained from the surface dumps the material was predominantly quartz with a little sulphide.

Several prospect pits were sunk on Wickersham Dome and on the ridge west of the west fork of Twenty-two Gulch. A claim named the Florence Lode was prospected by a trench and shaft, both now caved. At this property was a small pile of ore consisting of pieces of galena showing many cavities coated with malachite. The galena is fine-grained and contains considerable tetrahedrite. The prospect is situated at an elevation of 3,500 feet. Its location is shown by the appropriate symbol on plate 28 .

On a spur just west of the fork of Twenty-two Gulch at an elevation of about 2,700 feet is a prospect said to be owned by Otto Bosart. This property has been developed by two trenches and a shaft, 25 feet apart, along a line that strikes N. $40^{\circ}$ E. When visited the trenches were caved and the shaft was full of water, but a small pile of sorted ore showed that the principal mineral was galena, some of which was coarsely crystalline but most of which was 
finely crystalline. Associated with the galena were sphalerite and considerable tetrahedrite.

\section{MoGONOGILL}

The McGonogill claims are located on McGonogill Gulch, a small tributary of Glacier Creek near its source.

The upper claim lies at an elevation of about 3,400 feet. The vein, which is exposed at the surface and developed by a tunnel 40 feet long, strikes N. $58^{\circ}$ E., dips $34^{\circ} \mathrm{NW}$., and cuts graphitic schist. In the face of the drift 8 feet of mineralized quartz was exposed. The quartz is divided into bands about a foot thick which are separated by seams of altered schist 1 to 5 inches thick. The quartz contains veinlets and scattered crystals of pyrite and arsenopyrite. Galena and stibnite are said to occur in the quartz, but neither was seen by the writer.

Part of the tunnel on the lower vein was caved at the time of visit. The following description is taken from the report by Davis. ${ }^{33}$

The lower claim is also situated on the right limit of the [gulch] but approximately one-quarter of a mile toward the west and about 250 feet lower in elevation. The vein is exposed at the surface and consists of 18 inches of quartz which is free milling. One ton of ore from this outcrop was sent to a testing plant in Seattle and milled, yielding $\$ 80$ in gold. A crosscut tunnel was started from the bank of the [gulch] and driven to intersect this vein. At a distance of 30 feet from the portal it encountered a 3 -foot shear zone impregnated with gray copper, stibnite, and chalcopyrite, from which assays containing as high as 52 ounces of silver per ton was secured. This tunnel was extended 15 feet beyond this shear zone without encountering the freemilling quartz vein which it was driven to intersect. A crosscut was then driven 12 feet to the right of the tunnel along the shear zone, at the end of which the quartz vein was encountered. It was discovered that the vein had been faulted and displaced to the left and that the tunnel had been driven through the fault. The tunnel is 4 feet by 6 feet in the clear and is timbered for the first 25 feet.

\section{GLEN CREEK}

Glen Creek is one of the streams that has yielded a considerable amount of the placer gold produced from the district. The largest nugget was found in this creek, and many nuggets weighing from 1 to 7 ounces have been recovered there. Galena, stibnite, and pyrite are abundant in the concentrates. Boulders of rhodonite are found, and crystals of cassiterite reported to have come from the concentrates have been seen by the writer. Though these facts as well as the croppings indicate that the basin of Glen Creek is a favorable area for prospecting, little work has been done in the headwater region, and during the last few years the old workings have all caved.

as Davis, J. A., op. cit., p. 131. 
On the ridge between the West Fork of Glen Creek and Rainy Creek are several caved prospect pits and trenches. The country rock is a thinly foliated schist which strikes $\mathrm{N} .50^{\circ}-75^{\circ} \mathrm{E}$. and dips at varying angles southeastward. It seems from the distribution of the trenches that the veins are parallel in strike to the schistosity. The material lying on the surface is generally iron-stained quartz, usually with numerous cavities and containing crystals of pyrite, but in some specimens coarse crystals of pyrite predominate over the quartz. Some of the quartz contains a little galena.

GIEN

The Glen prospect is on the west slope of Glacier Peak. Development work on it consists of two tunnels, the lower one at an elevation of about 4,050 feet and the upper about 200 feet higher. The prospect, now the property of Lee Swisher, was formerly owned by a small group, Tom Lloyd having the controlling interest, and the tunnels were driven between 1906 and 1909 . Since then no work has been done, and the workings are now caved and filled with ice.

The country rock is a quartzose quartz-muscovite schist showing but little foliation, in which the trend of the schistosity is N. $20^{\circ} \mathrm{E}$. According to John Stendhal the lower tunnel is about 300 feet long and was driven along a vein that trends northeast. The vein is reported to consist of a quartz ledge about 4 feet wide and a zone of shattered decomposed rock, with bunches of galena scattered through the quartz. The upper tunnel is on the same vein, which can be traced by the float for about 300 feet westward. The material on the dump is mostly quartz, showing only small quantities of scattered sulphide; pyrite, galena, and sphalerite, stated in the order of their relative abundance, were recognized.

GLEN RIDGE NO, 1

C. A. Trundy has staked a claim, named Glen Ridge No. 1, on the crest of the ridge to the east of the West Fork of Glen Creek. Here the schist is much deformed. The top of the ridge is covered with quartz float, and large masses of quartz apparently in place crop out. Owing to the covering of surface material and the complexity of the structure, it was impossible to determine definitely the thickness, strike, and dip, but the vein appears to be about 20 feet thick, to strike $\mathrm{N} .65^{\circ} \mathrm{W}$., and to dip southwestward. The vein material is rusty quartz with numerous cavities, carrying some scattered finegrained galena and a little pyrite. Moffit ${ }^{34}$ reports free gold. The development work consists of a pit now 6 feet deep.

\footnotetext{
84 Moffit, F. H., The Kantishna district, Alaska : U.S. Geol. Survey Bull. 836, p. 334, 1932.
} 


\section{ARKANSAS AND PENSION}

All openings on the Arkansas and Pension claims, situated near the head of the West Fork of Glen Creek, were completely caved in 1931. Davis ${ }^{35}$ states that the discovery open cut at the Arkansas claim exposed

a mineralized zone about 14 feet wide, consisting of three bands of quartz separated by two bands of schist from right to left as follows: Five feet of quartz, 21/2 feet of schist, $1 \frac{1}{2}$ feet of quartz, $21 / 2$ feet of schist, $1 \frac{1}{2}$ feet of quartz. A grab sample taken by the writer across the 5-foot quartz band showed 90 ounces of silver per ton. The ore is chiefly sulphides of lead and antimony with some sphalerite.

\section{HUMBOLDT}

The following description of the Humboldt prospect, the property of John Stendhal, is in the main an abstract of the earlier published statement by Capps. ${ }^{36}$ The Humboldt prospect lies at the head of the East Fork of Glen Creek, on the high ridge that forms the crest of the Kantishna Hills, at an elevation of 4,250 feet. The schist here strikes N. $37^{\circ} \mathrm{W}$. and dips $27^{\circ} \mathrm{S} . \mathrm{W}$. A tunnel said to be 48 feet long, driven westward, was so caved at the time of visit that it could not be examined. This tunnel was apparently started on the cropping of a vertical quartz vein that strikes N. $55^{\circ} \mathrm{E}$., but it is said that the tunnel diverged from the vein and that no quartz. showed at the breast. The main vein is 3 to 4 feet wide and consists principally of milky-white quartz, but with somewhat stained and rusty quartz also present. It is massive and shows no noticeable banding but contains some small schist inclusions. Associated with the main vein are two or three smaller parallel veins, all lying within a zone that measures about 30 feet across. Numerous large pieces of vein quartz, broken from the cropping, lie on the surfacenear the mouth of the tunnel. This material contains small bunches and crystals of sulphide minerals scattered through it, and bunches of sphalerite and galena are reported to have occurred in the vein. No work has been done on the property for several years.

\section{SPRUCE CREEK}

Several prospect pits have been dug on the ridges forming the basin of Spruce Creek, but most of these have been abandoned. From the few pieces of iron-stained quartz lying on the surface near the caved pits it would seem that the pits were sunk on quartz veins. or stringers, the quartz usually containing some arsenopyrite or pyrite. The Spruce Creek No. 1 claim of C. A. Trundy, on the saddle between Spruce and Crevice Creeks, is on a vein of this type. The

Davis, J. A., op. cit., p. 132.

${ }^{20}$ Capps, S. R., op. cit. (Bull. 687), p. 99. 
vein, which is about 12 feet wide and strikes about N. $20^{\circ} \mathrm{E}$., is ironstained and shows a little pyrite mineralization. Two shallow pits have been dug on the vein, but they are both caved.

\section{IENA AND SILVER WIRE}

The Lena and Silver Wire claims both lie on the west slope of Spruce Peak, within the basin of Spruce Creek (see pl. 28), and both are owned by C. A. Trundy. The vein has been opened up by a series of trenches crosscutting the vein at intervals along the strike. Unfortunately all the trenches had caved, so the vein could not be seen in place. The country rock, a quartz-muscovite schist, strikes $N$. $60^{\circ}-70^{\circ} \mathrm{E}$., and according to Moffit ${ }^{37}$ the vein parallels the schistosity but dips at a high angle to the south, thus cutting the northwarddipping foliation of the schist. The vein as exposed in one open cut is 5 feet wide, and about one third is high-grade galena ore. The galena content becomes less to the east along the strike. According to Mr. Trundy, a sample of the ore assayed half an ounce in gold to the ton and had a total value in gold, silver, and lead of $\$ 90$ a ton during the time of high prices for silver following the World War.

\section{NORTH STAR}

The North Star claim held by Mr. C. A. Trundy, is on the north slope of Spruce Peak within the drainage basin of Crevice Creek. The slope is strewn with talus, but at one place a stream has cut a small trench about 6 feet deep. In the bank of the stream a vein 2 feet wide, composed of quartz, galena, sphalerite, and pyrite crops out. The country rock is a thinly laminated chloritic schist, the schistosity of which strikes N. $25^{\circ}$ E. and dips $65^{\circ} \mathrm{SE}$. The vein, however, dips $65^{\circ} \mathrm{SE}$. Much coarsely crystalline galena float is scattered in the talus to the southwest, and Mr. Trundy said that at one place where he cleared away the talus he found a 6-foot vein of galena. This was covered when visited by the writer. The large amount of coarse talus on this slope shows that there has been considerable sliding, so it is possible that rock apparently in place is part of a large block which has suffered some movement.

\section{GLDORADO CREEK}

AIPFA

In the summer of 1931 all the workings of the Alpha claim were caved. Lawrence Ferrara, who now owns the claim, had dug out the vein at one point from which it was possible to obtain a few specimens. Here the vein consists of 1 foot of hard iron-stained galena with cavities. The material on the dump was largely jame-

${ }^{97}$ Moftlt, F. H., The Kantishna district, Alaska : U.S. Geol. Survey Bull. 836, p. 333, 1932.

$179399-33-4$ 
sonite with some sphalerite and crystalline quartz. Considerable siderite is found with the ore. The galena from the vein assayed 0.01 ounce of gold and 374.2 ounces of silver to the ton and 5.46 percent of lead. Davis ${ }^{38}$ gives the following description of the Alpha claim:

The Alpha claim lies near the top of the hill on the Eldorado Creek side, about a mile from Moose Creek. The development work consists of a tunnel 120 feet long, the first 100 feet of which is timbered, and a shaft 20 feet deep situated 60 feet $\mathrm{S} .2^{\circ} \mathrm{W}$. from the end of the timbering. The vein matter is highly iron-stained quartz and contains sulphides and oxides of lead and copper. The bottom of the shaft exposed a mineralized zone 8 or 9 feet wide containing three bands of highly mineralized iron-stained quartz, each about 1 foot in width. Something over a ton of ore was sorted and sacked from the material excavated in sinking this shaft. A grab sample of this ore assayed by the Bureau of Mines showed 266.30 ounces of silver per ton.

\section{NEVERSWEAT}

The Neversweat claim, the property of John Busia, is located on the south side of Eldorado Creek at the junction of Reinhart Creek. Here the side of the valley is covered by a talus of large blocks of quartz porphyry, and in this talus are found many large pieces, consisting principally of coarsely crystalline galena with some pyrite and chalcopyrite. A tunnel a few feet above the creek level was driven for more than 40 feet into an area of schist included in the porphyry but failed to encounter a vein, though a little mineralized schist was found. Two open cuts, one 100 feet and the other 150 feet up the hill, failed to locate the vein in place. A sample of the ore ran 55 percent of lead and 74 ounces of silver and $\$ 10$ in gold to the ton.

\section{ANTIMONY PROSPECTS}

Stibnite is found both in the placer concentrates and as large cobbles and boulders in all the creeks of the district that have been worked for placer gold, and owing to the conspicuous nature of the vein outcrops it was the first mineral to be mined from lodes (p. 353). Stibnite float is especially abundant in Glen, Eureka, and Eldorado Creeks. No lodes of stibnite have been worked in the drainage basin of Glen Creek. Mr. Quigley states that two lodes of stibnite on the south bank of Eureka Creek were opened up by trenches, but in the summer of 1931 no trace of the lodes could be found. Mr. Quigley likewise reported a stibnite lode on the north slope of Eldorado Creek, but neither he nor the writer was able to locate it even after much searching.

\section{SLATE CREEK}

The workings at the antimony prospect on Slate Creek were completely caved when visited in 1931, so the vein could not be examined.

Davis, J. A., op. cit., p. 131. 
There was several tons of ore on the dump. The ore is almost pure stibnite, but some pieces show quartz gangue. Capps, ${ }^{39}$ who visited the prospect in 1916, gives the following description in his report:

The Taylor mine, or, as it is commonly called, the Antimony mine, lies near the head of Slate Creek, a headward tributary of Eldorado Creek. The property was first staked in 1907, but the title lapsed and the ground was restaked by the present owner. It is said to include a group of claims, but the work done has been confined to the driving of a tunnel 97 feet long, with 22 feet of crosscuts, and to the excavation of an open cut immediately above the tunnel. The open cut and the tunnel show a strong fissure along which movement has taken place. This fissure strikes $\mathrm{N}$. $50^{\circ} \mathrm{E}$. and dips $82^{\circ} \mathrm{SE}$. and forms the southeast wall of the main ore body, though a little ore is seen on its southeast side. The ore body has a maximum width of 15 feet and constitutes a reticulated stockwork of quartz and stibnite, with irregular bunches and horses of decomposed clayey schist, all much broken and confused. The enclosing quartzite schist strikes north and dips $29^{\circ} \mathrm{E}$.

Almost pure stibnite occurs here in veinlets and in veins, the largest 2 feet thick, and in irregular lenses and bunches. In some places it is solid and unaltered, but in others it is crushed and broken and consists of small fragments of quartz and stibnite recemented by yellow and reddish secondary oxidation products, which on analysis are found to consist of the antimony ochers, stibiconite and kermesite. The principal ore bodies, which occur within 6 or 8 feet of the main fissure, seem to lie in the stockwork with their longest diameter oblique to the main fissure, the ore lenses and veinlets in general dipping $60^{\circ} \mathrm{NW}$. The stibnite occurs predominantly as aggregates of acicular crystals but includes also masses of fine-grained material. About 125 tons of hand-sorted stibnite has been mined, most of which was taken from the open cut. That taken from the tunnel was of lower grade, as the pure stibnite occurred there in smaller bunches, and the ore contained more quartz and schist. In the absence of facilities for machine concentration much stibnite that could not be separated from the gangue by hand sorting was thrown on the dump.

\section{HOME LODE}

W. M. Julian has staked a claim called the Home Lode on the west bank of Crevice Creek about 1 mile above its mouth. Some work had been done on the lode, but it was sloughed when visited, so the vein could not be seen in place. The country rock is a quartzmuscovite schist. Small showings of quartz stained by iron oxide and yellow oxidation products of stibnite and containing a little stibnite were seen. The quartz has been brecciated and cemented by later quartz.

\section{CARIBOU}

Capps ${ }^{40}$ describes the Caribou lode as follows:

Caribou lode, in the basin of Caribou Creek, near the mouth of Last Chance Creek, a tributary from the southeast, is a stibnite-bearing lode on which some development work has been done. This property was visited by Prindle in 1906, and the following description is written from information gathered by Prindle and by the writer. Little work has been done on the property since

sa Capps, S. R., op. cit. (Bull. 687), pp. 107-108.

s0 Idem, pp. 108-109. 
1906, and at the time it was visited in 1916 the shafts were full of watet and inaccessible. The property consists of two lode claims, the Pioneer and the Caribou, which lie across the lower valley of Last Chance Creek. Two shafts have been sunk-one, 40 feet deep, on the west bank of Last Chance Creek, and another, 30 feet deep, on the east bank. The vein strikes N. $40^{\circ} \mathrm{E}$. and dips about $67^{\circ}$ SE., is about 4 feet wide, and consists of a mixture of quartz and stibnite. In the western shaft a vein of pure stibnite 1 foot wide is said to lie along the northwest wall and to become narrower toward the bottom of the shaft. The quartz is massive to crystalline and is intimately intergrown with the stibnite, which occurs as a mixed aggregate of finegrained massive sulphide intermingled with acicular crystals, the largest 2 inches or more in length. Within the coarsely crystalline stibnite there are mingled many long prisms of quartz, which lie parallel with and are surrounded by the stibnite. The country rock enclosing the vein is much contorted hornblende schist, the general strike of which is $\mathrm{N}$. $65^{\circ} \mathrm{E}$. and the general dip $35^{\circ} \mathrm{NW}$. On Caribou Creek, several hundred feet northeast of the shafts, is an outcrop of a fissure that strikes $\mathrm{N}, 45^{\circ} \mathrm{E}$. and dips $75^{\circ} \mathrm{SE}$. It is believed to be the continuation of the antimony lode but shows only a little quartz.

Three samples of antimony ore collected from this property in 1906 were assayed. One yielded 4 ounces of silver to the ton, one 2.76 ounces of silver and 0.12 ounce of gold, and the third 0.12 ounce of gold but no silver. Another sample, assayed for gold only, yielded 0.02 ounce to the ton. No ore from this lode has been marketed.

\section{SUMMARY}

To sum up the conclusions reached as to the mineral resources of the Eureka and vicinity area, it may be said the area warrants further prospecting. Much of it is practically untouched, and none of it has been thoroughly prospected. Exploration along the strike and down the dip of the known veins would probably reveal additional ore, and further prospecting would probably uncover new lodes. From what is now known concerning the nature of the mineralization and the relation of the different types of veins to one another it is clear that sulphide-bearing quartz veins, though carrying only small quantities of metals where exposed, may elsewhere contain shoots of gold ore or large lenses of silver-bearing galena and sphalerite. Many such veins have been staked in the past and are now abandoned. The small amount of trenching and drifting done on these veins was not sufficient to explore them thoroughly.

Many facts clearly indicate that the most highly mineralized area and the one in which prospecting seems most justified is a tract about 2 miles wide that runs from Slate Creek to Spruce Peak and includes the drainage basins of Eldorado, Eureka, and Friday Creeks, upper Glacier Creek and its tributaries, Twenty-two Gulch and Yellow Creek, and Glen Creek. These creeks have furnished all the placer gold, and boulders and pebbles of galena and stibnite are found there. The axis of an anticlinal fold of the schistosity as well as the outcrops of the igneous dikes follow this line. Furthermore, the belt of outcrop of the limestone and chlorite schist occupies the central part of this area. 


\section{INDEX}

\begin{abstract}
Page
Abstract of report_-_._._-_-_-_._ 335-336

Accessibility of the area_._._._. 336-337

Acknowledgments for aid_._-_.-_ 338-339

Alpha claim

Antimony prospects

Arkansas claim_-_._-_-________- 374

Assays of ore-_._. $363,364,365,367,368$, $369,370,372,374,375,376,378$
\end{abstract}

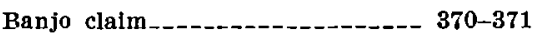

Birch Creek schist, age and correla-

tlon of -

character and subdivisions of - 343-346

thickness and origin of _..._..- 346

Capps, S. R., quoted

369, 377-378

Caribou antimony lode_._._._._. 377-378

Chlorite schist, occurrence of, in Birch Creek schist_..- 346

Climate_._.

Damon and Pythias claim_-_-_-_ $\mathbf{3 7 1}$

Davis, J. A., quoted_ $367,370,372,374,376$

Diabase, occurrence and character of $\quad 348$

Drainage 339-340

Eldorado Creek, prospects on

Eureka and vicinity, geologic map of _._._._-_ pl. 28 (in pocket)

Eureka Creek, sketch map of lode claims in vicinity of_- pl. 29

Fleld work

Foreword, by Phillp s. Smith..._. v-vilI

Francis claim. 368

Friday Creek, sketch map of lode claims in vicinity of _-_ pl. 29

Galena claim_-_._. 367-368

Galena-sphalerite veins, features of -- 358

Gangue minerals, character of

Geologic history -._-_-__-_.-- 351-352

Geologic map of Eureka and viclnity

(in pocket)

Geology, principal features of

Glaciation and glacial deposits_-_- $\mathbf{3 4 9 - 3 5 0}$

Glacier Creek, prospects on

Glen Creek, prospects on_._._. 372-374

Glen prospect_..._._._._._._. 373

Glen Ridge No. 1 claim _._. 373

Gold D o $11 \mathrm{a} \mathrm{r}$ and Golden Eagle claims

Gold quartz veins, features of -- $357-358$

Gravel deposits, postglacial____-_ 350-351

Home Lode claim

377

Humboldt clalm

374
Igneous rocks, occurrence and character of --_--_---- 347-348

Keystone claim _..._.

Lena claim

Limestone, occurrence of, in Birch

Creek schist_-..- 345

Little Annie claim_-_-- 364-366, pls. 31, 32

Little Maud claim_____._-_._-_ 368-369

Location of the area._._._._. 336

Lucky Strike claim.

McGonogill clalms________-_ 372

Merry Widow claim_... 371

Metallic minerals, occurrence of, in velns _._-___-_ 356-357

Mining, economic factors affecting - $\mathbf{3 6 0}$ history of

Neversweat claim_____-_- 376

North Star claim

Ore, genesis of

Ore deposits, mineralogy of oxidation and enrichment of - 358-359 structural features of

Pennsylvania claim

Pension claim _._._-_._-_._._. 374

Polly Wonder claim

Population of the area...... $342-343$

Quartz-muscovite schist, character and distribution of -- 343-344 structure of

Quartz porphyry, oceurrence and character of

Quaternary deposits, occurrence and character of

Quigley Hill, mines and prospects on-1-_- 360-371

Red Top claim._._._. $361-364$, pl. 30

Relief in the area_._._._._. 340

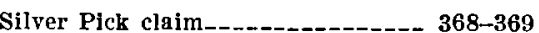

Silver Wire claim_________-_-_ 375

Slate Creek, antimony prospect on $376-377$

Spruce Creek, prospects on

Stibnite veins, features of

Summary of conclusions_._._._- $\quad 378$

Surveys of the area, previous_-_-_ 337-338

Vegetation

341-342 




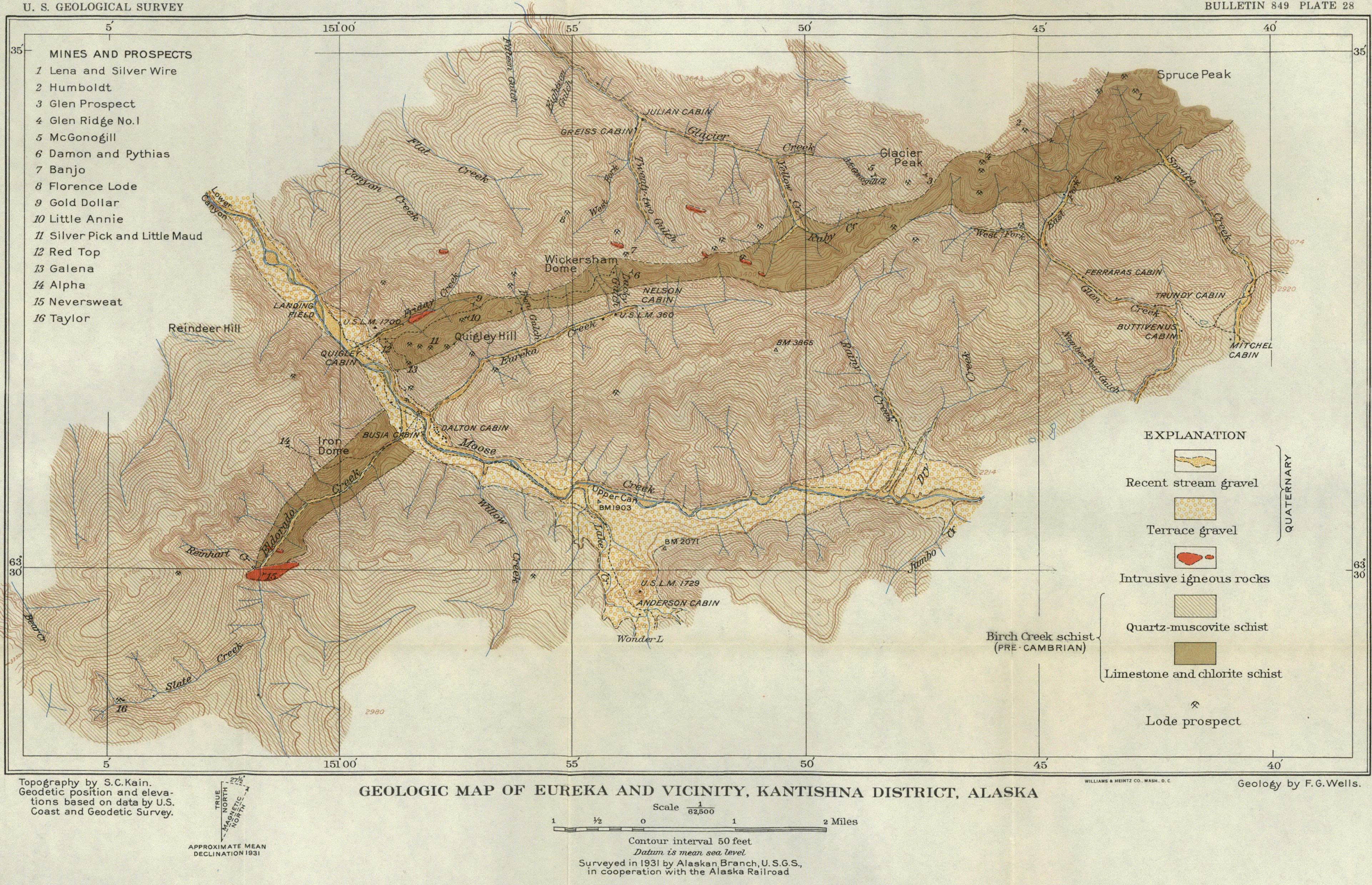
